\title{
Prestar en tiempos de guerra, cambio institucional y transformaciones sociopolíticas. El crédito notarial en Salta 1810- $1835^{*}$
}

\section{Lending during Wartime, Institutional Change and Sociopolitical Transformations. The Notarial Credit in Salta, 1810-1835}

\author{
Marcelo Gabriel Anachuri** \\ Becado Doctoral por el Consejo de Investigación (CIUNSA) \\ Facultad de Ciencias Económicas- Facultad de Humanidades \\ Universidad Nacional de Salta, Argentina \\ https://orcid.org/0000-0002-4127-2665 \\ gabrielanachuri2016@gmail.com
}

\section{Resumen}

Este artículo se propone analizar la dinámica crediticia en la ciudad de Salta (Argentina) ante los sucesos revolucionarios de 1810, momento en el cual se asistió a un estancamiento económico y reordenamiento de los

Este trabajo recibió el apoyo del Consejo de Investigaciones de la Universidad Nacional de Salta (CIUNSa), Proyecto Tipo A/ No 2340, del cual el autor forma parte y se desempeña como becado doctoral por dicha institución.

** Agradezco a las y/o los evaluadores por el tiempo invertido en las sugerencias y comentarios efectuados para mejorar la versión preliminar del presente artículo. Se deja en claro que cualquier error, confusión o vacío es responsabilidad propia. 
antiguos circuitos comerciales en la región del Tucumán, hasta 1835, año en el cual se evidencia una gradual recuperación. Se propone ahondar en interrogantes sobre los cuales se considera que el crédito notarial arroja luz acerca de la incidencia de la economía local sobre los cambios políticos e institucionales tras el desmoronamiento del orden virreinal y la creciente desigualdad regional en el virreinato del Río de la Plata. Lo anterior permitirá analizar el influjo del cambio, la transformación y las continuidades sobre una economía de Antiguo Régimen, con base en en la dimensión estructural-relacional del crédito y su correlación con la dinámica comercial a la cual financió. Se relevó documentación inédita, como la totalidad de compromisos crediticios registrados y las obligaciones de pago ante los escribanos locales resguardadas hoy en el Archivo Histórico de Salta. Por sus características notariales, estas escrituras permite identificar la evolución de aristas fundamentales del crédito, tales como plazos estipulados, destino del préstamo, garantías exigidas, tasas de interés y distribución espacial, así como reconstruir las relaciones sociales desde el universo relacional de los agentes que concentraron mayor transacciones crediticias.

Palabras claves: crédito, historia económica, comercio, Salta.

Códigos JEL: N51, N14, F1.

\section{Abstract}

This article studies the credit dynamics in the city of Salta (Argentina) during the revolutionary events from 1810, a year characterized by an economic stagnation and the rearrangement of the old commercial circuits in the Tucumán region, until 1835, in which a gradual recovery was evidenced. This work intends to delve into questions about which the author considers that the notarial credit sheds some light on the impact of the local economy over political and institutional changes after the collapse of the viceregal order and the growing regional inequality in the Viceroyalty of Río de la Plata. This will allow analyzing the influence of change and transformation over an Old Regime economy, focusing on the structural-relational dimension of credit and its correlation with the commercial dynamics it had previously financed. Unpublished documentation was released as all credit commitments recorded as payment obligations were protected in the Historical Archive of Salta. Due to its notarial characteristics, this works allows to identify the evolution of fundamental credit edges such as stipulated terms, destination of the loan, required guarantees, interest rates, spatial distribution 
and reconstruct social relations from the relational universe of the agents that concentrated the greatest deed of credit transaction.

Keywords: Credit, economic history, commerce, Salta.

JEL Codes: N51, N14, F1. 


\section{INTRODUCCIÓN}

La deuda y el crédito son variables fundamentales que dinamizan las economías y estructuran complejas y asimétricas relaciones sociales. Los modos en los cuales se le ofrece sentido a la práctica crediticia y al endeudamiento son plurales. Para comprender efectivamente los flujos crediticios, es necesario ofrecer una visión integradora de los vínculos entre relaciones sociales, universos culturales y tradiciones mercantiles. Las prácticas económicas son parte indispensable de los lazos sociales y se desarrollan en un contexto de relaciones tanto impersonales como íntimas, envueltas en afecto y confianza.

Como práctica social e histórica, el crédito resultó de suma importancia para el desenvolvimiento de las actividades comerciales en la ciudad de Salta (Argentina) a finales de la era virreinal y principios del siglo XIX. En su dinámica intervinieron diversas instituciones, aparatos normativos, jurídicos o contractuales y necesidades de todo tipo que llevaron a los agentes contemporáneos a acudir a su demanda; desde adquirir productos básicos para la alimentación, la construcción o alquiler de una vivienda, hasta el financiamiento de los rubros mercantiles y productivos sindicados como los más relevantes de la plaza salteña, como es el caso del envío de mulas a los polos potosinos y la redistribución de los efectos de castilla importados del comercio exterior. En este sentido, el crédito notarial otorgó los engranajes financieros a la circulación local, regional y transregional, sobre las cuales desplegaron sus negocios actores radicados en Salta, como vecinos, residentes o en tránsito, hacia latitudes regionales.

Como se verá más adelante, al identificar los agentes que concentraron mayor cantidad de obligaciones de pago, se puede apreciar que estos comúnmente complementaron poder económico con cargos políticos y sostuvieron complejos vínculos relacionales, favoreciéndolos al momento de establecer compromisos crediticios, puesto que dispusieron tanto del sustento material, como relacional para afianzar sus operaciones. A pesar que esta práctica consuetudinaria se mantendría tras la revolución, no limitó, la puesta en escena de nuevos agentes en el círculo.

En términos estructurales, la coyuntura revolucionaria afectó considerablemente la dinámica comercial y a sus resortes últimos de financiación, como el crédito. En comparación al periodo tardo-virreinal, el estancamiento tanto en el volumen de valores acreditados como en el número de escrituración de créditos pueden considerarse algunos de los signos con 
los cuales la economía salteña participó del proceso de obstrucción en la circulación y creciente desigualdad interregional que se incrementó tras la revolución en el virreinato del Río de la Plata.

De esta manera, los datos recabados y el análisis realizado permiten inferir que la revolución y sus efectos políticos e institucionales, afectaron la fluidez crediticia y las actividades comerciales financiadas por esta. Al analizar las obligaciones de pago también es posible introducir la mirada social desde los actores reconocer la indicencia negativa que tuvo el contexto bélico al momento de otorgar o acceder a compromisos crediticios.

El análisis microanalítico también aproxima a los complejos y asimétricos entramados relaccionales del grupo que concentró mayor disponibilidad crediticia. Algunos personajes como Pablo Aleman (el mayor acreedor del periodo analizado), José Hilario Carol o Juan Galo Leguizamón, fueron prósperos prestamistas salteños que estratégicamente sortearon las disquisiciones del momento, se ubicaron políticamente en la comunidad local y pueden ser sindicados parte recambio generacional de una sociedad salteña que transitaba de una fidelidad regia a una fidelidad estatal.

La región de la Intendencia de Salta del Tucumán, particularmente su capital homónina, fue territorio de guerra por más de quince años, situación coyuntural que terminó por ahondar un comportamiento deficitario hacia la baja en los volúmenes acreditados de años anteriores. De esta manera, la revolución y sus consecuencias económicas no produjeron el inicio de la tendencia negativa en los comportamientos crediticios, sino que la profundizaron a niveles muy bajos, dando paso a un periodo estacionario y de paralización de la actividad crediticia (gráfica 1). En suma, tras la revolución, las transacciones crediticias salteñas se caracterizaron por un estancamiento absoluto, tanto en el volumen de los valores acreditados como en la cantidad de obligaciones de pago escrituradas. A pesar de que esta tendencia mejoró gradualmente desde 1825 , superado los años de mayor enfrentamiento bélico en el espacio, dichas transacciones no volverían a alcanzar los montos de los últimos años virreinales.

Desde la constitución definitiva de Salta como la capital de la intendencia de Salta del Tucumán, el 7 de enero de 1784, hasta los meses previos al estallido revolucionario, se contabilizaron 563 compromisos crediticios y se transfirió un total de $\$ 3.325 .189$ pesos corrientes de a ocho reales (unidad monetaria que mantendrá a lo largo del trabajo). Tras la revolución y hasta 1835 se relevaron menos de la mitad a este número, solo se escrituraron ante 
los notarios públicos 212 compromisos crediticios y un total de $\$ 389.055$ pesos corrientes de a ocho reales. ${ }^{1}$

El comportamiento estacionario en la actividad crediticia se explicaría por el contexto bélico que atravesó la región y repercutió en los negocios de los agentes financiados por medio del crédito. En casi todos los espacios, la guerra tuvo altos costos sobre la fiscalidad y el comercio para poner fin a los vínculos con la monarquía hispánica. Pero el mapa es complejo, América Latina diversa y las consecuencias económicas múltiples. Lo propio del medio siglo que sigue a la caída del orden virreinal no sería ni la crisis ni el crecimiento, sino una variedad de situaciones en las que algunos de los países en proceso de constitución conocen acerca de declinación económica o estancamiento, mientras que otros crecían más o menos rápidamente (Gelman, 2011, p. 11).

Las diferencias en el proceso revolucionario fueron complejas y se presentaron al interior de cada uno de los antiguos virreinatos y entre las regiones y subregiones. Tras el desmoronamiento del orden virreinal, lo particular del virreinato del Río de la Plata fue el incremento de las desigualdades regionales y subregionales. Según Gelman:

“mientras Buenos Aires consolidó su expansión económica debido a la importancia creciente del mercado atlántico, en las economías regionales no hay crisis, pero tampoco crecimiento, sino divergencias. Fueron tiempos en los cuales se ahondaron las desigualdades regionales y la generación de una posterior Argentina macro fálica" (2011, p. 11).

Tomando como punto base las complejidades y diversidades regionales planteadas por la historiografía económica, este trabajo propone ahondar en interrogantes sobre los cuales el autor considera que el crédito notarial arroja luz sobre la incidencia dentro de la economía local de los cambios políticos e institucionales tras el desmoronamiento del orden virreinal y la creciente desigualdad regional en el virreinato del Río de la Plata. Esto permitirá analizar el influjo del cambio, la continuidad y la transformación sobre una economía de Antiguo Régimen, así como centrarse en la dimensión estructural-relacional del crédito y su correlación con la dinámica comercial a la cual financió. Para ello, se relevó documentación inédita como

La incertidumbre e inseguridad para establecer créditos de un periodo coyuntural puede advertirse en los propios actores. De hecho, la última operación de crédito previa al estallido revolucionario data del 28 de marzo de 1810. En esa oportunidad, el comerciante salteño Bernardo Arramburu, residente en Salta y vecino de San Carlos, se obligó por un préstamo de 300 pesos al síndico del convento San Francisco (AHS, Sección notariales, caja 23, protocolo 237, Fs 33 r). Luego de este compromiso, asistimos a un vacío de crédito hasta octubre de 1810. 
la totalidad de compromisos crediticios registrados como obligaciones de pago resguardada en el Archivo Histórico de Salta (en adelante, AHS).

Las fuentes históricas empleadas permiten identificar la evolución de aristas fundamentales del crédito, tales como plazos estipulados, destino del préstamo, garantías exigidas, tasas de interés y distribución espacial, además de reconstruir las relaciones sociales desde el universo relacional de los agentes que concentraron mayor escrituración de transacción crediticia, sus estrategias, vínculos, redes y dificultades afrontadas para acceder al financiamiento de sus actividades, en un entorno de elevados riesgos, especulación e incertidumbre. La mirada microanalítica propuesta permitirá reconocer el recambio y las continuidades generacionales que trajo la revolución dentro del grupo económica y políticamente dominante en la plaza salteña.

De esta manera, el artículo se estructura en dos apartados. Primero, se propone una contextualización demográfica y geográfica de la Salta de época, la evolución de variables fundamentales del crédito notarial, su correlación con otros indicadores económicos, el impacto de las guerras sobre sus movimientos y las dificultades que atravesaron los actores contrayentes y otorgantes de préstamos. A través de una mirada relacional que prioriza el punto de vista de los sujetos, el segundo apartado analiza la distribución del crédito entre sus agentes, los síntomas y lógicas de asignación, las redes entretejidas y los vínculos sociales que permiten aproximarse a sus complejas relaciones sociales y al recambio generacional de la élite económica salteña de aquellos años.

\section{Crédito, cambio político e institucional en una econo- mía en tránsito a una fidelidad estatal. Salta, 1810-1835}

La Intendencia de Salta del Tucumán quedó instalada definitivamente el 7 de enero de 1784. La ciudad homónina fue nombrada por real cédula capital de esta división administrativa, la cual controló política y administrativamente entre sus límites juridicionales las actuales provincias de Tarija, Jujuy, Catamarca, Tucumán y San Ramón de la Nueva Orán y abarcó una enorme extensión geográfica, así como una heterogénea realidad socioeconómica.

Al momento de caracterizar la ciudad de Salta, Acevedo la describió como "modesta y sencilla, pero con residencias cómodas y espaciosas. Situada al margen de un amplio valle y entre los ríos llamados Arias 
y Siancas, tenía su población resguardada de los vientos por una serranía" (1965, pp. 114-115). La población urbana radicada en la plaza salteña (en términos estimativos) osciló desde cerca de 5.000 habitantes en 1784 hasta 40.000 en $1825 .{ }^{2}$ Con este nuevo posicionamiento administrativo, la ciudad pasó a ser sede del gobernador intendente y despacho de las cajas reales mayores, a la vez que se benefició por los años de bonanza económica general que atravesó la región en su conjunto por aquella época (Gelman, 2014; Santilli, 2013). Así mismo, se acrecentaron los circuitos comerciales con Buenos Aires, aumentaron las actividades productivas volcadas al espacio peruano y se incrementó la población en las principales ciudades de la flamante intendencia. El mayor dinamismo económico experimentado por la región se vivió entre 1788 y 1793.

La ubicación geográfica de Salta le permitió gozar de ventajas absolutas en cuanto a la circulación virreinal en comparación con otras ciudades colindantes. Salta articuló y se vinculó a dos centros económicos gravitatorios. Por un lado, Potosí, polo minero del cual se extrajo y exportó más del 88 \% del material argentífero que circuló e inyectó economías orientales, bálticas, rusas, europeas y asiáticas, al punto que la difusión internacional del peso de plata hispanoamericano lo transformó en lo que podría considerarse un dinero metálico de circulación casi universal (Marichal, 2017, p. 37; Flynn \& Giráldez, 1995). Por otra parte, la ciudad aumentó su vínculo con Buenos Aires, centro político y administrativo, constituido desde 1776 en la capital del flamante virreinato del Río de la Plata, polo económico que conectó Salta y otras economías regionales con mercados distantes vía el océano Atlántico, consolidando su rol como núcleo exportador e importador, impulsado, en parte, por la industrialización del norte atlántico (Jumar, 2012, pp. 124-157).

El dinamismo comercial de la plaza salteña de los últimos años virreinales se plasmó en una mayor escrituración de créditos registrados como obligaciones de pago y rubricados por los escribanos públicos locales. Desde 1777 hasta los meses previos a la revolución de 1810 se contabilizaron 777 obligaciones de pago y se transfirieron un total de $\$ 4.151 .346$ pesos y 6 reales. El monto dinerario total transferido a crédito en Salta duplicó al de otros espacios hispanoamericanos del periodo. A modo de comparación, Santiago de Chile registró entre 1759 y 1798 un total de 906 compromisos

2 Datos demográficos estimativos extraídos del censo argentino de 1869 y del trabajo de Acevedo (1965, p. 115). Estas cifras son estimativas y no toman en cuenta el número de habitantes de la campaña. 
crediticios y transfirió un total de $\$ 2.194 .444$ pesos (Cavieres, 1996). Los volúmenes transferidos a crédito en el caso salteño siguen siendo significativos en relación con otros indicadores macroeconómicos. Según los datos de la caja real de la plaza, en aquellos años los principales ingresos fiscales, como las alcabalas, recaudaron un total de $\$ 534.518$, mientras que las sisas permitieron recaudar $\$ 1.216 .934 .^{3}$

Ahora bien, cabe aclarar que el comportamiento en los volúmenes acreditados a través de estas escrituras tendieron a ser muy volátiles. Así mismo, es de advertir que desde 1794 (gráfica 1) hay un quiebre que pareciera modificar el patrón de comportamiento crediticio, probablemente ello se explique por el contexto bélico de la monarquía y la recesión del comercio exterior que impactó en los negocios de los agentes salteños que solicitaban y otorgaban créditos para financiar la venta y redistribución de los denominados efectos de Castilla (Anachuri, 2019a, 2019b). Una vez que alcanzó su máximo histórico en 1805, con algunas oscilaciones, la tendencia a la baja no se detiene, profundizándose tras la revolución de 1810. De ahí en adelante, con algunos momentos de recuperación, ni los volúmenes acreditados ni la cantidad de escrituraciones alcanzarían las cifras de los últimos años virreinales.

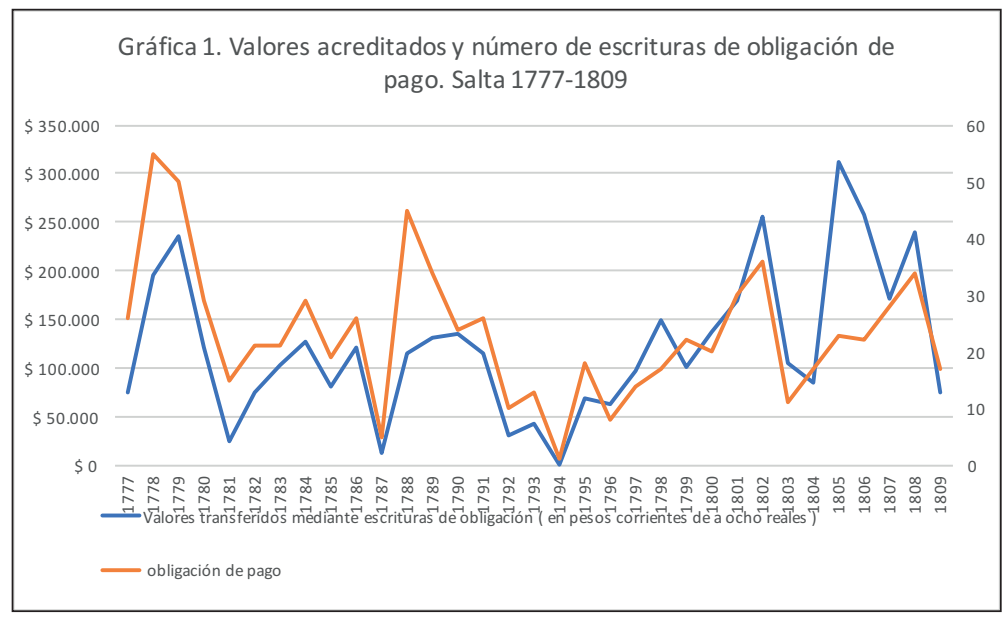

Los convulsionados sucesos políticos, sociales e institucionales desencadenados con la revolución incidieron directamente sobre algunas de las variables fundamentales del crédito notarial salteño. Esto tiene múltiples y complejas explicaciones que buscaremos reconocer a continuación. Valores referenciados de sisas, alcabalas e ingresos a favor de la Aduana local disponibles en el
repositorio estadístico "Cajas de la Real Hacienda de la América española". Disponible en línea y de acceso público en: https://realhacienda.colmex.mx/

\section{Gráfica 1.}

Valores acreditados y número de escrituras de obligación de pago. Salta 1777-1809

Fuente: Elaboración propia en base al relevamiento de las obligaciones de pago. Archivo Histórico de Salta sección protocolos notariales, carpeta núm. 147-231, protocolos núm. 147-231. 
Respecto a las características propias del proceso político que condujo a la monarquía hispánica a su crisis, implosión y fragmentación no fue el resultado de dos fuerzas opuestas destinadas a enfrentarse como placas tectónicas, sino producto de una suerte de desregularización de las fuerzas que componen la monarquía hispánica, que sintetiza y define como de naturaleza "vertical" y "horizontal". De este modo, la crisis de la monarquía desencadenó una crisis constitucional que involucró las dos dimensiones de la monarquía. La naturaleza transversal de esta crisis e implosión funcionó como vector de nuevas e imprevistas dinámicas que alimentaron los procesos revolucionarios y que abarcaron el periodo comprendido entre la revolución de los territorios y las independencias de los pueblos y las naciones (Quirós, 2015, p. 1-11).

Al momento de producirse la revolución en Buenos Aires, capital del virreinato del Río de la Plata, la Intendencia de Salta del Tucumán estaba gobernada por Nicolás Severo de Isasmendi, peninsular, comerciante y hacendado, casado con Jacoba De Gorostiaga Rioja, quien juró ante el cabildo local el cargo de gobernador intendente el 29 de abril de 1809 como sucesor de José de Medeiros. Tiempo después, hallándose envuelto en conflictos facciosos con el obispo y el cabildo, Isasmendi se vio obligado a solicitar su relevo y renunciar al cargo el 20 de abril de 1810, tras lo cual el virrey Cisneros designó al teniente de dragones Joaquín Maestre con calidad de interino el 11 de mayo de 1810, ante la imposibilidad legal en la cual se encontraba Isasmendi. No obstante, el militar Maestre nunca llegó a ocupar el cargo real de gobernador de la intendencia, continuando Isasmendi al frente, aunque bajo una situación prácticamente insostenible. Finalmente, la Junta Provisional Gubernativa de Buenos Aires terminó por relevarlo del mando y en su reemplazo nombró al coronel de ejército Feliciano Chiclana el 16 de julio de 1810. Este nombramiento, tanto por la autoridad de la cual provino como por la ruptura de vínculos de dependencia que la Junta estableció, implicó el gradual inicio de una nueva etapa política e institucional (Acevedo, 1965, p. 404).

Las consecuencias económicas de estos cambios trascendentales fueron disímiles para todas las regiones, lo cual también se evidenció al interior de cada una de estas. Mientras que Buenos Aires experimentó una expansión económica debido a la importancia del proceso de atlantización de la denominada primera globalización (Bonialian \& Hausberger, 2018), las economías regionales no experimentaron crisis, pero tampoco 
crecimiento, sino más bien profundos desequilibrios. La historiografía regional descartó la idea de una crisis generalizada en los antiguos circuitos comerciales que vincularon la región del Tucumán a los polos potosinos. Las articulaciones montadas en tiempos del antiguo régimen subsistieron. Son alteradas, pero no quebrantadas. Aun cuando el estallido de la revolución convirtió la región del Tucumán en zona de guerra por más de quince años, los antiguos caminos comerciales no lograron desestructurarse (Conti \& Jumar, 2010).

Al realizar la nomenclatura de las acciones militares que tuvieron lugar en la región, identificamos que los años con mayor grado de enfrentamientos se ubicaron prácticamente en toda la primera década revolucionaria (1810-1818). Estos encuentros bélicos combinaron guerra a campo abierto con guerra irregular e implicaron movilizar recursos para crear y mantener las fuerzas armadas, sin importar la magnitud del número de hombres y de bajas. Entre 1810 y 1825 se produjeron en el espacio un total de 44 enfrentamientos (75\% sobre el total en el territorio del Río de la Plata desarrollados en el periodo). A la vez, los enfrentamientos intercalaron ocupaciones a la ciudad de Salta por tropas fieles al rey: 29 de enero-10 de marzo de 1812; 15 de abril-4 de mayo de 1817, por José de la Serna; 31 de mayo-fines de junio de 1820, por Juan Ramírez Orozco; 7 de junio-14 de julio de 1821 por Pedro Antonio de Olañeta, última invasión y ocupación registrada.

El 97,2 \% del total de enfrentamientos se concentró en la primera década posrevolucionaria. Es un momento de posiciones políticas disímiles y apertura de numerosos frentes. Además, la intensidad del conflicto convergió en un gradual proceso de militarización de la sociedad salteña, movilizando a sectores urbanos y rurales, lo cual contribuyó a definir identidades y liderazgos políticos en los que el entramado de relaciones se definió a partir de vínculos clientelistas y paternalistas no exentos de conflictos (Mata, 1999, p. 175). Esta coyuntura histórica incidió directamente sobre la economía local y el crédito en una sociedad que comenzó a vivir, literalmente, para la guerra. En términos económicos, hubo una necesidad inevitable por captar mayores recursos para mantener fuerzas por parte de los flamantes estados, situación que alteró las estructuras fiscales vigentes.

Al referirse a la fiscalidad salteña de aquellos años, Justiniano y Tejerina (2011) subrayaron que esta: 
"se caracterizó por mantener el esquema impositivo tardo colonial. Las principales fuentes de recursos para la provincia fueron los derechos de alcabala, la sisa, diezmos y las contribuciones, sean estas voluntarias o forzosas. El imperio de la costumbre se convertía en el dispositivo racional sobre el que se pretendía edificar la arquitectura impositiva de los tiempos tempranos de la independencia. Esta apelación a la usanza puede registrarse tanto en los marcos legales y jurídicos como en las misivas de los funcionarios y en las quejas de los contribuyentes. Los gravámenes a la circulación comercial, como alcabalas y sisas, continuaron siendo el principal ingreso de la hacienda salteña" (p. 2).

El estancamiento relativo de la circulación comercial tras los primeros años de la revolución se correlacionó con un comportamiento errático en los volúmenes acreditados por estos principales ingresos fiscales provenientes, justamente, de una actividad mercantil por el momento paralizada. Lo cual limitó la recaudación de las arcas fiscales salteñas y conllevó años de déficit por la caja recaudatoria local (gráfica 2 y anexo 1). En este contexto, se asistió a una necesidad imperiosa del circulante que conllevó aumentar los empréstitos forzosos, levas y desplazamientos de población

Gráfica 2. por avances y retrocesos de las tropas (Conti, 2003). Según Parolo (2016):

Evolución de los ingresos a favor de la hacienda y los gastos de guerra en Salta, 1810-1835 (\%)

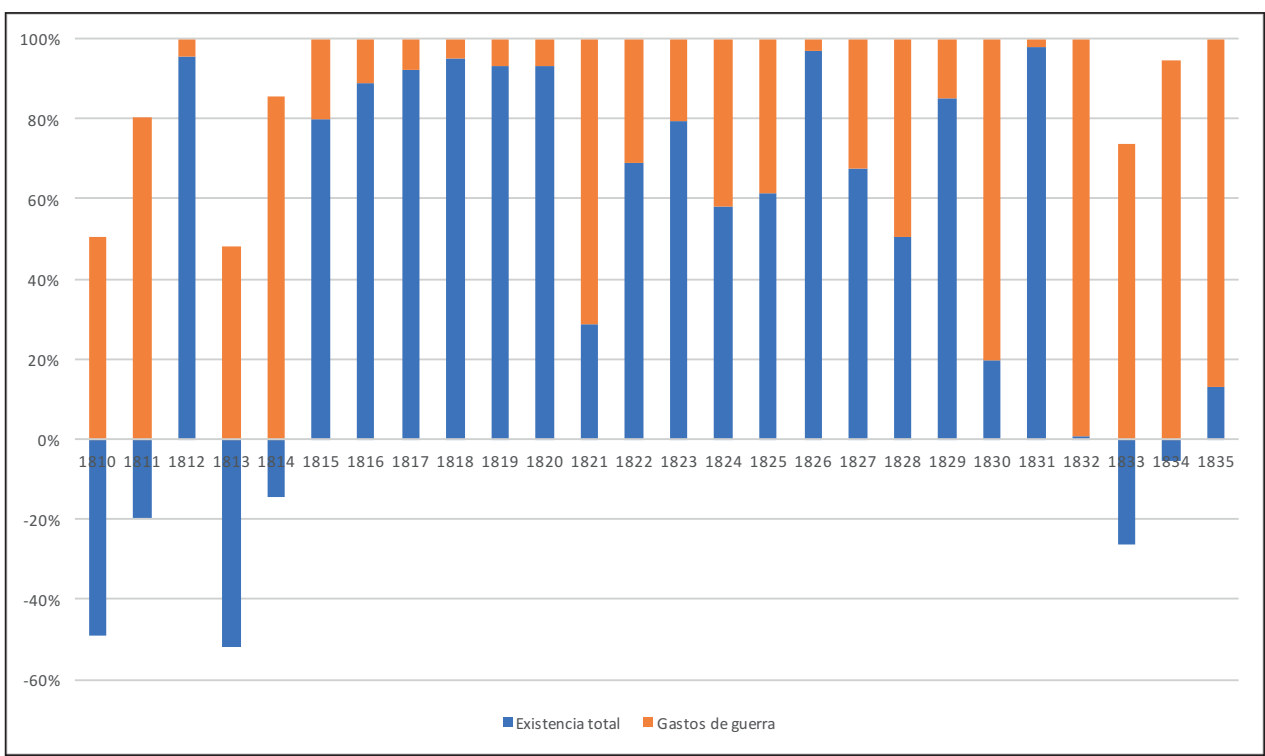

Fuente: Elaboración propia con base en AHS, Sección: Hacienda.

Libros Mayores (1810-1835). Nota: valores en términos 
"más allá de los caminos divergentes y de las particularidades de cada uno de los itinerarios fiscales individuales, la región presentaba un aspecto convergente: un periodo de penurias, desequilibrios y déficit hasta 1840 y un lento y disímil proceso de estabilización y recuperación a partir de ese año" (p. 17).

El aumento exponencial en gastos bélicos en el caso salteño alcanzó el $70 \%$ y tuvo que ser sustentado, en su gran mayoría, por fondos locales. Ello se reflejó en años deficitarios para la hacienda local entre 1810 y 1815 (gráfica 2). Es de esperar, entonces, que al disminuir y estancarse la dinámica comercial, el crédito notariado, principal medio de financiación de la circulación, acompañe este ciclo estacionario.

Entre 1810 y 1835 se contabilizaron 212 compromisos crediticios registrados como obligación de pago ante los notarios públicos salteños, transfiriéndose un total de $\$ 389.055$ pesos en moneda corriente de a ocho reales. En comparación con los últimos años virreinales, esta caída fue profunda y abrió paso a un escenario socioeconómico desigual para la circulación comercial desde múltiples perspectivas. Por un lado, Potosí no reconoció la junta de Buenos Aires, por lo cual suspendieron el envío de dinero a la plaza porteña. Este hecho condicionó las prácticas de apropiación y/o uso de recursos pertenecientes a la monarquía para favorecer el enriquecimiento y los intereses de los grupos de poderes económicos, políticos y sociales locales, puesto que el Real Situado otorgaba una oportunidad para financiar compromisos crediticios de sujetos radicados en ciudades como Salta, por la cual se trasladaban los fondos reales hasta Buenos Aires. ${ }^{4}$ En segundo lugar, aumentaron la confiscación de tierras para abastecer al ejército patriota. Las mulas y el ganado vacuno, unas de las ramas más importantes del comercio regional, fueron los principales

4 Por ejemplo, el 20 de marzo de 1797, Manuel Ortiz Villada, comerciante y vecino de Salta, adquirió un compromiso crediticio por $\$ 34.170$ a favor de Domingo Funes, comerciante y vecino de Córdoba, para invertir en una partida de mulas. Al momento de establecer la forma y los plazos de cancelación manifestó “(...) remitirá desde la villa del Potosí en el mes próximo de abril con el situado de su cuenta, costo y riesgo a la ciudad de Córdoba y a entregar al contenido Domingo Funes veinte mil pesos en plata sellada doble: seis mil pesos que en los mismos términos remitirá con el situado que deberá salir de dicha villa por el mes de octubre venidero a la ciudad de Córdoba y el resto hasta el entero de la total cantidad ponerlo y entregarlo en esta ciudad para la próxima saca de mulas del año venidero" (AHS, Sección protocolos notariales, caja núm. 18, protocolo núm. 183, fs. 19r).

Las lógicas de la costumbre y las prácticas consetudinarias continuaron siendo fuertes en estas sociedades. Como subrayó hace ya algunos años Hespanha (1996) " Coexistían, en primer lugar, diferentes centros autónomos de poder, sin que esto acarreara problemas, ni de orden práctico ni de orden teórico. La sociedad era concebida como un cuerpo; esta metáfora ayudaba a comprender que, como los diferentes órganos del cuerpo, así los diversos órganos sociales podían disponer de la autonomía de funcionamiento exigida por el desempeño de la función que les estaba atribuida en la economía del todo" (p. 13). 
perjudicados. Además, no debe olvidarse que la producción se habría reducido considerablemente, teniendo en cuenta que la mayoría de los sujetos reclutados para las tropas revolucionarias provenían de zonas rurales.

Ante este contexto hostil en materia económica, es apreciable la sensibilidad tanto en los fondos acreditados como en la cantidad de escrituración crediticia efectuada. A medida que se transita el periodo de mayores enfrentamientos bélicos sobre los cuales tenemos mención en el territorio (1810-1818, 97 \% del total), los volúmenes acreditados a través de estos instrumentos notariales disminuyen gradualmente, al igual que la cantidad de escrituración de obligaciones de pago para iniciar la década del veinte con una gradual y tímida recuperación (gráfica 3).

Gráfica 3. Número de conflictos, valores acreditados y operaciones rubricadas como obligación de pago en Salta, 1810-1835

Fuente: Elaboración propia con base en AHS, Sección Notariales, Protocolos notariales, Carpetas 23-28, protocolos desde el número

237 al 298 (periodo 1810-1835). Nota: sobre los conflictos armados que se sucedieron en la región ver Mata (1999).

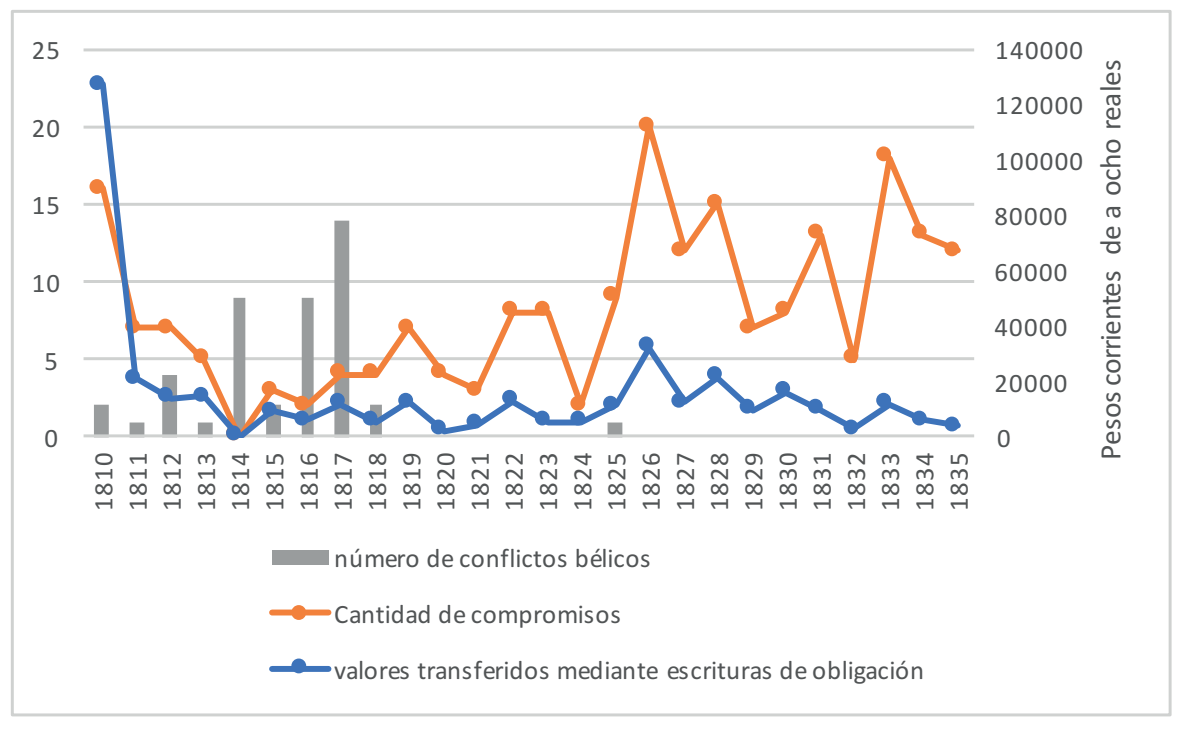

La relación es elevada entre los años de mayores enfrentamientos, los valores acreditados y el número de compromisos escriturados. Entre 1810 y 1818 disminuyó la cantidad de créditos otorgados y la cancelación de estos $y$, en efecto, asistimos a un porcentaje mayor de escrituras crediticias no canceladas.

Recuérdese que el pago de una obligación constituía su cumplimiento. De esta manera, el el deudor principal, sus fiadores (si los había) y sus herederos quedaban liberados de la obligación personalmente asumida por el primero. A la extinción de la obligación personal y sus posibles garantías reales le correspondía la carta de pago, la cual podía aparecer como documento independiente o como una nota al margen que cancelaba la escritura de obligación (Wasserman, 2018, pp. 175-177). 
Fueron canceladas notarialmente el 35,37 \% (75 boleta de pago) sobre el $100 \%$ (212) de las escrituras de obligación registradas. El 64,63\% de los compromisos crediticios que se llevaron a cabo en aquellos años no fueron revocados. Al respecto, puede señalarse que el porcentaje de escrituras de créditos no canceladas crece en la primera década posterior a la revolución, que es, además, la época en la que se despliega el mayor número de enfrentamientos armados en la región (1810-1818).

La revolución abrió paso a un escenario poco propicio para la dinámica crediticia, en particular, y comercial, en general. En efecto, la especulación, la incertidumbre y los elevados riesgos estuvieron a la orden del día, tal como manifestaron los propios agentes en sus compromisos crediticios (gráfica 4).

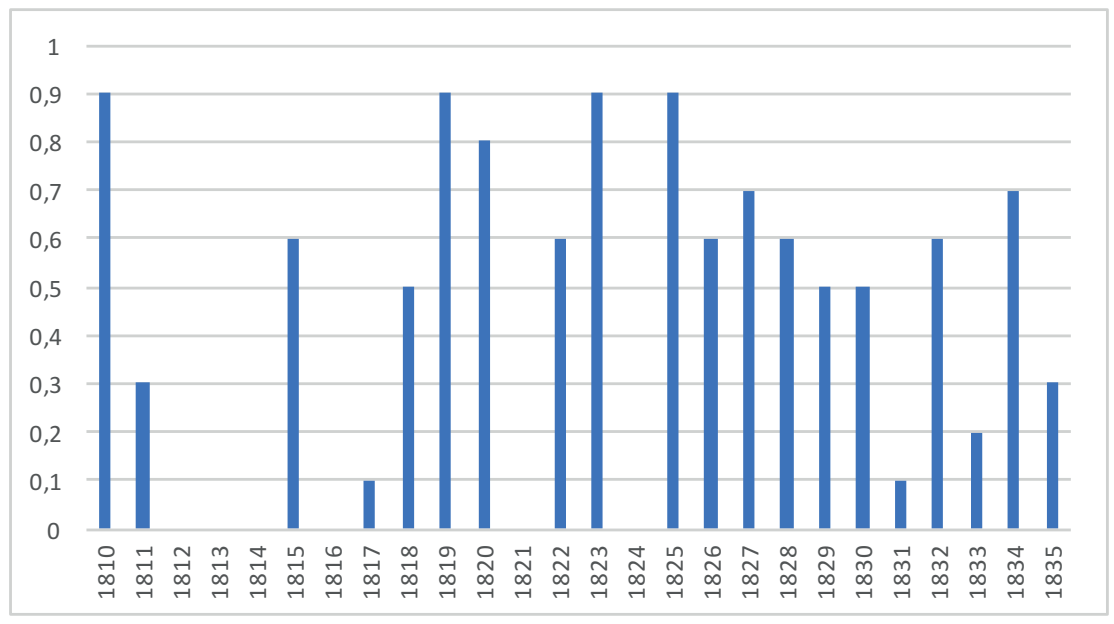

Existen casos en los que se dejo constancia textual en el cuerpo de la obligación de pago sobre las dificultades atravesadas al momento de otorgar, recibir o cumplir en tiempo y forma los plazos del reintegro de la deuda. Por ejemplo, el 26 de julio de 1816, Lorenzo Maurín, estanciero, comerciante y jefe militar de uno de los escuadrones de gauchos al mando de Martín Miguel Güemes, manifestó sus aprietos para cancelar un crédito de 4.697 pesos a favor de Fernando López en los siguientes términos:

"[...] solo entrega dos mil novecientos noventa y siete pesos tres reales, según todo consta de los documentos que tiene firmados: en esta virtud y por la restante cantidad de mil setecientos pesos que por los acontecimientos de la actual revolución no ha podido abonar otorga por la presente a favor del expresado Fernando y los suios [...]".5

\section{Gráfica 4.}

Porcentaje de compromisos crediticios no cancelados en Salta

Fuente: elaboración propia con base en AHS, Sección Notariales, Protocolos notariales, Carpetas 23-28, protocolos desde el número 237 al 298 (periodo 1810-1835). Nota: en los años en los que no figura porcentaje de deudas canceladas (i) se realizó la cancelación de la totalidad de los créditos o (ii) no se registró ninguna transacción crediticia. 
Las cambiantes y diversas posiciones políticas ocasionadas por el avance y retrocesos de tropas en la región condicionaron la disponibilidad y el reintegro de préstamos. Este fue el caso del comerciante oriundo de la ciudad de La Plata y residente bajo la condición de emigrado en la plaza salteña, Manuel Morales, quien se reconoció "líquido, llano y verdadero deudor" de Juan Díaz, Alférez de Salta, por 400 pesos provenientes de algunos efectos sustraídos a Lucas Arrieta. En la obligación de pago el deudor aclaraba que "luego que se abra el Pirú sea pagado por mi llanamente en el acto a cuyo efecto obligo mis muebles y raíces habidas y por haber en toda forma". ${ }^{6}$

Los años de relativa calma fueron momentos oportunos para exigir la cancelación de deudas pendientes, con plazos e intereses vencidos. Algunos acreedores aprovechaban estas circunstancias, e incluso acudían a instancias judiciales, para reclamar el reintegro del empréstito. Este fue el caso de la prestamista María Magdalena Aguirre, viuda del comerciante y político salteño Manuel Antonio Boedo, quien el 13 de enero de 1819 siguió un juicio contra Petrona Elorriaga en el juzgado ordinario de segundo voto de Salta por 2.000 pesos que prestó en 1799. Veinte años después de esta operación, la acreedora reclamaba ante la justicia el embargo de las propiedades de su deudora.?

De esta manera no solo se puede apreciar la mora en el reintegro de las deudas de años anteriores, sino también la participación activa de las mujeres en el círculo crediticio salteño. Aunque en esta oportunidad el objetivo no es debatir directamente sobre la visibilización o no de la mujer en el ámbito comercial salteño, tema de por sí interesante y necesario, que demandaría un ensayo aparte, la presencia de estas mujeres, provenientes de la generación de esposas viudas de comerciantes salteños tardo-virreinales, permitiría cuestionar la vana concepción que predominó en la historiografía tradicional en torno a que la función de la mujer era cuidar y velar por la familia en sus diferentes facetas como hija, hermana, esposa y madre. Por el contrario, las fuentes históricas consultadas registran también los capitales prestados por las mujeres, quienes utilizaron los mismos recaudos normativos que los varones, dando cuenta que ellas jugaron un papel significativo en la economía salteña como comerciantes, prestamistas y/o representantes legales de sus esposos o padres al momento de realizar cualquier tipo de negocio, como el caso anteriormente citado. ${ }^{8}$

\footnotetext{
AHS, Sección protocolos notariales, caja núm. 25, protocolo núm. 264, fs. 9v.

AHS. Sección protocolo notariales. caja núm. 12. protocolo núm. 262, fs. 2 r.

8 Para una aproximación al estudio de mujeres prestamistas ver Truyol (2017).
} 
Estas mujeres no fueron los únicos agentes que dan cuenta de las dificultades y disquisiciones propias de una etapa coyuntural en el reintegro de los préstamos. Otro caso fue el del comerciante Lorenzo Aparicio, quién exigió el pago de dos créditos que había otorgado en 1806 y 1809 a Juan José Fernández Campero, ex Márquez de Javi, por 9.000 pesos en los siguientes términos:

“[...] por medio de su hijo Don Apolinario Aparicio le devolvió 1.000 pesos, quedando a deber solamente líquidos los ocho mil pesos que, por estos, juntas las diligencias del cateo a firmar que se practicó en ocho de enero y consiguiente información sobre la realidad, ha solicitado al compareciente la devolución total de la mencionada cantidad por el administrador Don José Ruiz el pago siguiente. Primero debe dicho administrador unos mil pesos y después, al fin de cada año, de mil en mil hasta completar dichos ocho mil pesos [...]".9

A partir de lo anterior, se aprecia que el promedio en los plazos de reintegro quedó determinado más por las coyunturas políticas atravesadas que por la dilatación temporal de los intercambios comerciales regionales. Los tiempos de cancelación (en términos mensuales) tiende a la baja a medida que se supera el periodo de mayor intensidad conflictiva. Si para 1810 y 1818 el pago del $90 \%$ de las obligaciones escrituradas oscilaron entre 15 y 30 meses, desde 1822 el $95 \%$ de estas no superaron el año como reintegro estipulado. Esta situación señalaría que entre 1810 y 1818 las obligaciones de pago se emplearon como instrumentos de financiación de mediano a largo plazo, mientras que desde 1822 en adelante se constituyeron en escrituras de crédito a corto plazo (gráfica 5).

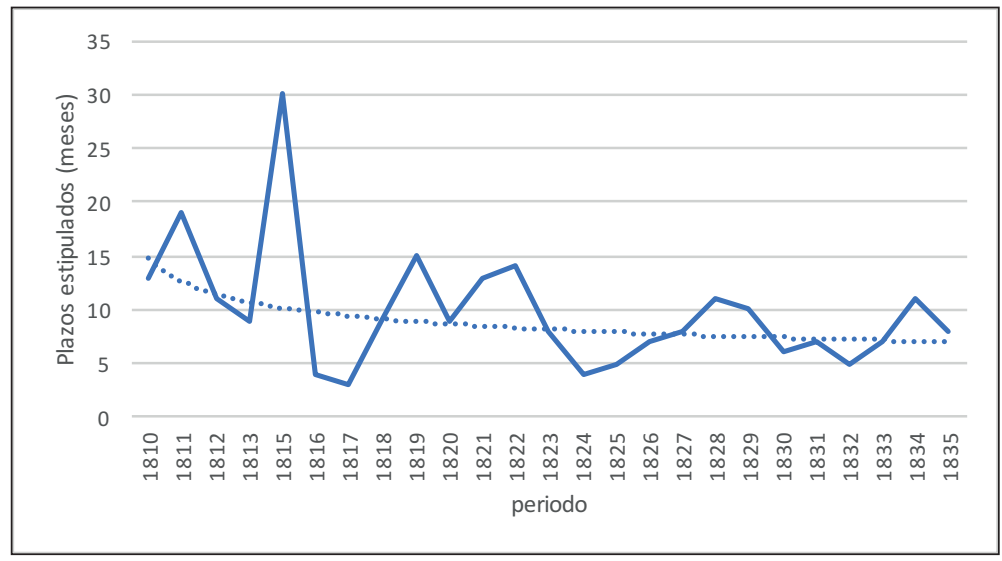

El periodo de mayor escrituración de obligaciones de pago en Salta tendió a concentrarse en el primer semestre del año, con una mayor frecuencia
Gráfica 5.

Promedio en los plazos estipulados de reintegro

Fuente: elaboración propia con base en AHS, Sección Notariales, Protocolos notariales, Carpetas 23-28, protocolos desde el número 237 al 298 (periodo 1810-1835). Nota: se desagregó en el campo "plazo estipulado de reintegro". 
de compromisos efectuadas entre los meses de marzo a julio. Esto permite plantear dos cuestiones (tabla 1). En primer lugar, que el mayor volumen de escrituración se concentre en esos meses, evidencia la persistencia de ferias mercantiles realizadas desde tiempos virreinales en inmediaciones a la plaza salteña. A estas ferias asistieron múltiples agentes con intereses y responsabilidades diversas, tales como productores de mulas de jurisdicciones de Córdoba, Santa Fe y Buenos Aires, junto con los invernadores salteños -comerciantes que otorgaban los medios de financiamiento necesario para emprender el envío de las bestias a los polos potosinos a través de diferentes formas de crédito- y compradores de diferentes latitudes americanas. De alguna manera, esto coincidiría con aquellos estudios que subrayan que a pesar de la situación conflictiva de los primeros años posrevolucionarios, Salta continuó siendo un importante centro mercantil transregional con vínculos mercantiles hacia mercados del litoral, altoperuanos y el Pacífico (Conti, 2003).

En segundo lugar, esta información permite comprender que las escrituras de obligación siguieron empleándose mayoritariamente para sostener los compromisos comerciales de aquellos intercambios desplegados tras la celebración de las ferias mercantiles salteñas entre verano y otoño, lo cual sugiere que el crédito notariado en este periodo fue un instrumento utilizado para sostener el comercio mular, la venta, adquisición o redistribución de los efectos de castilla, la moneda corriente/préstamo monetario (empleado en un $80 \%$ para acceder a la compra de efectos de castilla), la cancelación de cuentas y la construcción o el alquiler de inmuebles y otros suplementos de consumo cotidianos.

Tabla 1. Periodo de escrituración de obligaciones de pago en Salta, 1810-1835

Fuente: Elaboración propia en base a AHS, Sección Notariales, Protocolos notariales, Carpetas 23-28, protocolos desde el número 237 al 298 (periodo 1810-1835).

\begin{tabular}{|c|c|c|}
\hline Meses & Número de obligaciones & Porcentaje sobre el total (\%) \\
\hline Enero & 16 & 7,54 \\
\hline Febrero & 15 & 7,07 \\
\hline Marzo & 38 & 18 \\
\hline Abril & 17 & 8,01 \\
\hline Mayo & 21 & 10 \\
\hline Junio & 18 & 8,4 \\
\hline Julio & 27 & 12,7 \\
\hline Agosto & 15 & 7,21 \\
\hline Septiembre & 11 & 5 \\
\hline Octubre & 11 & 5 \\
\hline Noviembre & 8 & 4 \\
\hline Diciembre & 15 & 7,07 \\
\hline
\end{tabular}


Según los datos analizados, a pesar de la coyuntura revolucionaria, su ciclo estacionario y la teórica "anemia monetaria", el crédito monetario (emitido en préstamos en moneda corriente de a ocho reales) se constituyó en la principal naturaleza material del objeto del crédito (gráfica 6). Obsérvese que la transferencia de créditos monetarios fue habitual durante el periodo 1810-1835. Aún así, esta particularidad no escapó a los problemas y dificultades acaecidas por la diversidad de monedas y las formas de pago que comenzaron a emplearse en la región tras el desmoronamiento del orden virreinal; situación que se manifestó por los propios agentes emisores y receptores del crédito, sobre todo a partir de la década del veinte, cuando, según Conti (2003):

"circularon dos tipos de moneda: la moneda o peso fuerte $=10$ dinero, 20 gramos $=542$ gramos de peso y la moneda feble: 8 dinero, 666 milésimo de ley, principal estímulo del comercio, asistiendosé de esta manera a una desvalorización de la moneda de Buenos Aires, los comerciantes se negaban a vender y recibir en papel moneda y demandaron que se realizaran las transacciones en plata u onzas de oro" (p. 121).

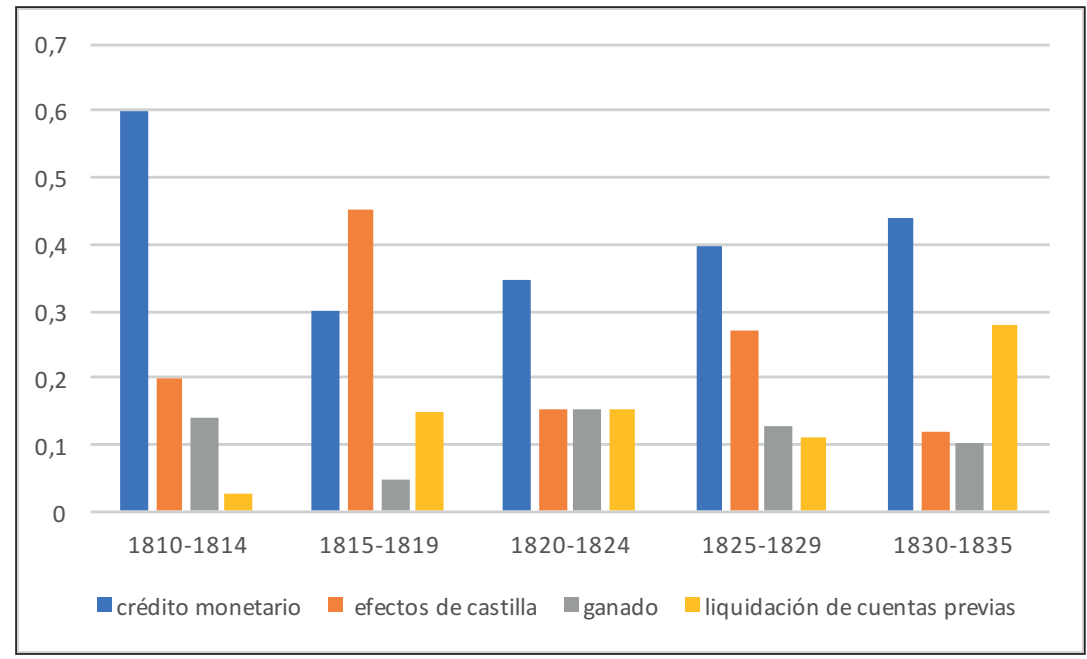

Gráfica 6.

Objeto del crédito en Salta, 1810-1835

Fuente: elaboración propia con base en AHS, Sección Notariales, Protocolos notariales, Carpetas 23-28, protocolos desde el número 237 al 298 (periodo 1810-1835). Nota: se desagregó en el campo analítico "naturaleza del objeto del crédito".

Por ejemplo, el 18 de noviembre de 1826, Francisco Allende, político y comerciante salteño, quien otorgó un crédito por 2.241 pesos a José Miguel Díaz Vélez, al momento de establecer el material de reintegro de la deuda aclaró su preferencia en "plata acuñada, dinero sellado de rostro peso fuerte $u$ oro sellado y no en papel moneda u otra cualesquiera especies". ${ }^{10}$ La especulación y preferencia sobre el tipo de moneda ante las cambiantes emisiones monetarias de los flamantes estados provinciales estuvo presente en los agentes otorgantes de créditos al momento de acordar la devolución de

AHS, Sección protocolos notariales. caja núm. 26. protocolo núm. 276, Fs. 100v. 
la deuda. Este fue el caso del prestamista José Benito Graña, quien subrayó en una obligación a su favor el 29 de julio de 1829 recibir de reintegro solo y únicamente "moneda sellada y no en papel moneda, ni en otra cualesquiera clases de moneda que se estableciere en lo sucesivo o se hallare ya establecida como nos tienen acostumbrados".11

Por otra parte, es posible que el contexto de la primera década posrevolucionaria incrementase los requerimientos de una garantía material endeble que respalde el compromiso crediticio y otorgue una seguridad relativa al acreedor en un entorno de elevados riesgos, especulación e incertidumbre propios de la coyuntura histórica. El 51,41\% de las obligaciones de pago contabilizadas durante el periodo analizado fueron respaldada por alguna garantía material. El 48,59 \% restante se apoyó bajo el aval normativo de la cláusula de obligación general de bienes en la cual el deficitario gravaba su compromiso de deuda con "su persona y bienes habidos y por haber" reforzada por la imposición de sometimiento a las justicias y "renunciando el fuero domicilio y vecindad".

Dentro del porcentaje de escrituras avaladas con una garantía material, la hipoteca inmobiliaria tuvo preponderancia (gráfica 7). Esta garantía puede ser subdivida en dos categorías: (i) propiedades urbanas, constituidas comúnmente por casas y/o tiendas edificadas en la ciudad o sus alrededores más próximos, y (ii) propiedades rurales. Por ejemplo, el comerciante salteño Luís Refojos, al momento de respaldar el crédito de 270 pesos que recibió de Seferina Escolástica Robles el 29 de enero de 1811, otorgó como hipoteca de la deuda:

Objeto material hipotecado

(\%) en el compromiso crediticio

Fuente: elaboración propia con base en AHS, Sección Notariales, Protocolos notariales, Carpetas 2328, protocolos desde el número 237 al 298 (periodo 1810-1835). Nota: Se tomó como referencia los compromisos que emplean garantías materiales.

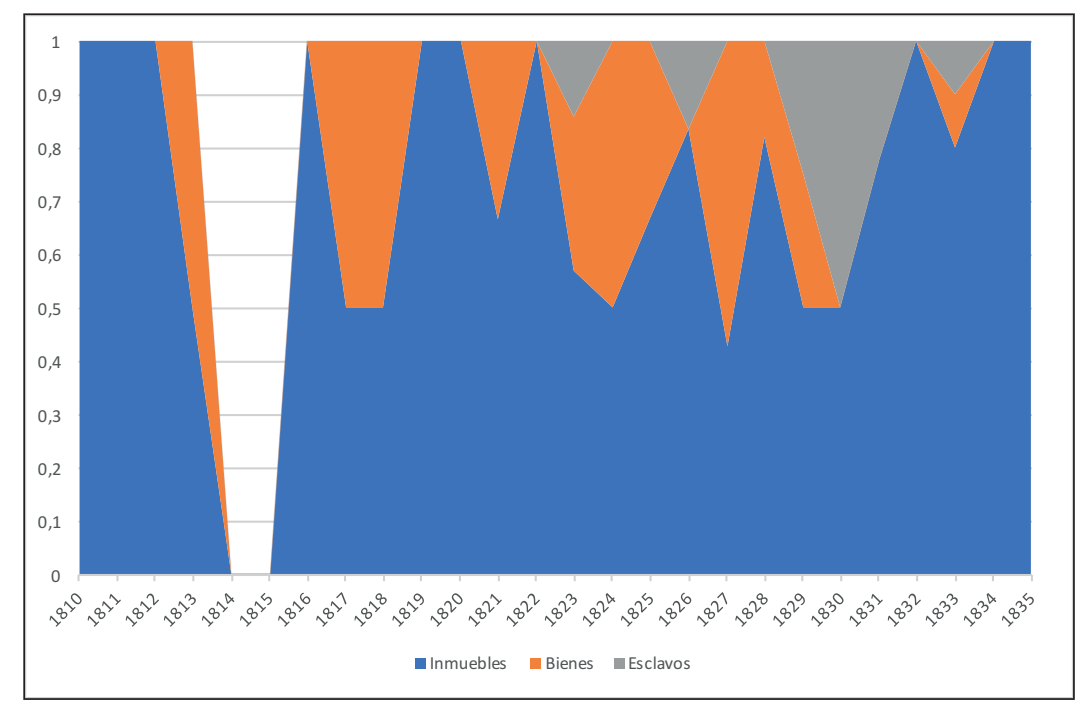

11 AHS, Sección protocolos notariales. caja núm. 27. protocolo núm. 280, Fs. 56r. 
La casa de su morada situada en la plaza mayor de esta ciudad de los límites y linderos que constan denotados en los títulos de propiedad de ella para que sin perjuicio de la obligación general en sus vienes pueda usar de la especial o por el contrario ambas juntas [.....$^{12}$

Respecto a las hipotecas de propiedades rurales, los actores solían emplearlas como garante de la deuda cuando esta superaba los 500 pesos. Estas posesiones hipotecadas no solo incluyeron las edificaciones con sus distintos mobiliarios, sino también los ganados con los cuales contaba. A modo de ejemplo, Martín Torino, el 8 de enero de 1828, se obligaba por un préstamo de 900 pesos a favor de Manuela Silveti Castellanos. Al momento de establecer la garantía material del compromiso manifestó hipotecar "la estancia que tiene y posee nombrada La Trampa con todos sus ganados existentes y todo lo que se halla sin más gravamen como se acostumbra". ${ }^{13}$

\section{Distribución del crédito notarial en Salta. Prácticas, vín- culos y actores contrayentes}

En una sociedad con población inestable, inserta en luchas internas de grupos, basada en una lógica corporativa de entramados relacionales donde la conciencia de la costumbre y los usos consuetudinarios eran especialmente fuertes en la que sus agentes negociaron la coexistencia del intercambio económico y de las relaciones sociales íntimas, acceder al crédito notarial no fue sencillo, aun cuando se contaba con un respaldo económico y material considerable. Esto se evidencia cuando tomadores de crédito de escasa reputación social en el universo relacional crediticio demandaban de la figura de un agente fiador, quien aparte de pagar en nombre del primero, en algunos casos se constituía en un garante y seguro del compromiso. Por lo general, los fiadores del crédito contaban justamente con un capital relacional que no poseía el tomador de la deuda. El fiador pasaba automáticamente "de causa ajena a suya propia y de libre deudor a obligado con su persona bienes y por haber".

El 6 de mayo de 1811, Benito Sáenz acudió a Manuel Antonio Tejada para que este sea fiador de un crédito por 2.762 pesos a favor de Pascual Díaz. Tejada fue un reconocido comerciante, político y militar del mundo tardío virreinal salteño y ejemplo de prolongación de un miembro de

12 AHS, Sección protocolos notariales, caja núm. 23. Protocolo núm. 242, Fs. 8r.

13 AHS, Sección protocolos notariales, caja núm. 35. Protocolo núm. 280, Fs. 2 r. 
la élite económica diesiochesca tras los procesos revolucionarios. El éxito en el mundo de los negocios de Manuel Antonio Tejada fue vertiginoso. En 1781 declaró un patrimonio neto de 58.788 pesos, ocho años después en 1789 duplicó esta cifra y alcanzó los 137.367 pesos corriente reales de a ocho. Estas cifras lo ubicarían en el grupo de los sujetos más ricos de la región, en particular, y del virreinato, en general. Como rasgo significativo, debe indicarse que Tejada mantuvo esta posición tras la revolución, lo cual hizo de él un sujeto al cual acudieron deudores de escasa reputación o agentes que gradualmente comenzaban a posicionarse en esa sociedad en transformación -pero con evidentes rasgos de continuidades paralelamente- para asegurarse al acceso al crédito.

No obstante, llama la atención cómo, a pesar de que el círculo del crédito notariado salteño continuó regulado por dinámicas relacionales que reforzaron el cumplimiento de los compromisos, la distribución de las escrituras entre quienes participaron en las obligaciones de pago evidencia que la oferta en la cantidad de compromisos crediticios otorgado por los acreedores tendió a verse poco más concentrada que la distribución de esa cantidad entre los deudores (gráfica 8). Las escrituras fueron distribuidas entre los actores contrayentes y otorgantes de forma escasamente concentrada. La poca concentración del crédito salteño entre los que mayores escrituras otorgaron (deudores) o recibieron (deudores) y los que menos lo hicieron da cuenta que la distribución de escrituras entre los agentes que participaron del círculo crediticio fue escasamente concentrada. Incluso las escrituras estuvieron mejor distribuidas entre los deudores que entre los acreedores.

Como puede apreciarse en la gráfica 8, mientras que la concentración entre prestamistas se incrementa, la distribución de escrituras ofrecidas por los deudores atraviesa un fenómeno inverso y tiende a disminuir a lo largo del periodo analizado. Se aprecia mayor concentración entre 1816 a 1826. En esa década el coeficiente de HHI pasó de 346entre 1810-1815 a 450 en el periodo 1816-1821 y 407 entre 1822-1826.

Posiblemente, esta tendencia se explique por redes menos densamente conectadas entre prestamistas y deudores durante dicho periodo, la cual se vio afectada por riesgos en los caminos y la incertidumbre de los actores debido al aumento de los enfrentamientos bélicos y las luchas de facciones políticas; situación que habría conducido a concentrar la transferencia de fondos crediticios en los pocos tomadores con capital relacional 


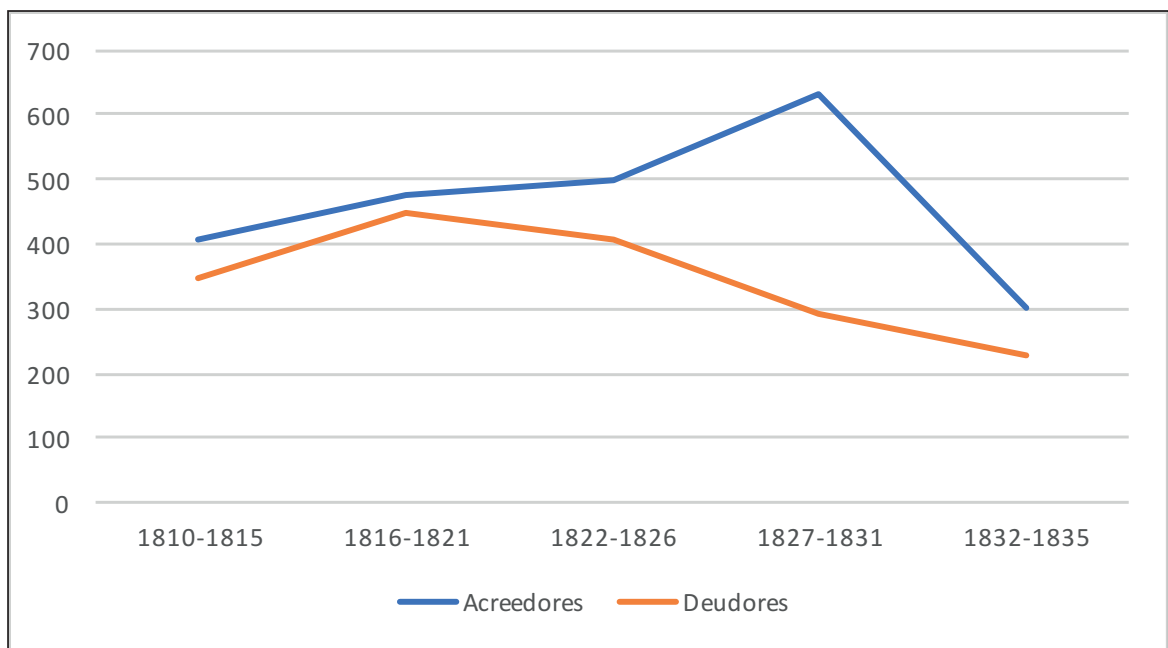

reconocibles e identificables (tabla 2), como Domingo Olavegoya, quien concentró el 62,25 \% del total de escrituras otorgadas en esos años.

El principal tomador de crédito de ese periodo (1810-1815) arribó a estos confines de la monarquía hispánica a mediados del siglo XVIII. Se afincó definitivamente como vecino en Potosí, plaza en la cual se dedicó a la actividad comercial, vinculándose con otros comerciantes salteños. Su capacidad para articular económicamente estos circuitos regionales lo condujo a formar en 1800 una compañía con José Rincón y Andrés del Castillo, quienes además de invertir en el comercio mular fueron relevantes mineros limeños. A esta asociación mercantil se sumó más adelante el estanciero santafesino Francisco Candioti, lo cual significó una competencia importante para estos ganaderos, puesto que hasta los últimos años del periodo virreinal la Compañía de Olavegoya, Rincón y Castillo monopolizó la actividad ganadera en la región (Mata, 2000).

Según Justiniano (2008):

"en el contexto de las insurgencias, los intereses mercantiles, sobre todo de aquellos que estaban dedicados al comercio mular con el Alto Perú, se vieron afectados. Comerciantes potosinos y limeños como José Gómez Rincón y Domingo Olavegoya, vinculados por matrimonio con familias salteñas, se concentraron en la compraventa de mulas y desplazaron de esta actividad a hombres como José lbazeta, estanciero también dedicado a la actividad comercial. Esta situación también dividió aguas
Gráfica 8.

Concentración en las escrituras de obligación entre deudores y acreedores. Salta 1810-1835

Fuente: Elaboración propia con base en AHS, Sección Notariales, Protocolos notariales, Carpetas 23-28, protocolos desde el número 237 al 298 (obligaciones de pago periodo 1810-1835).

Nota: El índice de HerfindahlHirschman (HHI) permite medir el grado de concentración. En el caso del presente análisis, permite identificar la concentración por número de créditos otorgados por acreedores y fondos tomados por deudores. Se calculó el índice de $\mathrm{IHH}$ a partir de la siguiente fórmula: $H H=\sum_{i=1}^{N} s_{i}^{2}$. A medida que el índice se aproxima a 1.000, se está ante una mayor concentración. 
TIEMPO \& ECONOMÍA

Vol. 7 N. ${ }^{\circ} 1$ | Enero - Junio del 2020

pp. $210-245$

Tabla 2.

Deudores que concentran

la principal cantidad de escrituración de obligaciones de pago en cada periodo

\begin{tabular}{|c|c|c|c|}
\hline Periodo & Deudor/a & $\begin{array}{c}\% \text { obligaciones } \\
\text { recibidas }\end{array}$ & $\begin{array}{c}\text { Grado de } \\
\text { concentración }\end{array}$ \\
\hline \multirow{3}{*}{$1810-1815$} & Domingo Olavegoya & 7,89 & 62,3 \\
\hline & Luis Refoxos & 5,26 & 27,7 \\
\hline & Pedro Pablo Mogrovejo & 5,26 & 27,7 \\
\hline $1816-1821$ & Manuel Victoriano Andrade & 8,33 & 69,4 \\
\hline \multirow{5}{*}{$1822-1826$} & Pedro Gary & 12,50 & 156,3 \\
\hline & Marcos Salomé Zorrilla & 4,16 & 17,3 \\
\hline & Eusebio de los Santos & 4,16 & 17,3 \\
\hline & Matías Vidal & 4,16 & 17,3 \\
\hline & Pedro González & 4,16 & 17,3 \\
\hline \multirow{6}{*}{$1827-1831$} & Matías Agois & 9,09 & 82,6 \\
\hline & José Loreto Cabrera & 5,45 & 29,7 \\
\hline & Julián González & 3,63 & 13,2 \\
\hline & Luis del Castillo & 3,63 & 13,2 \\
\hline & Mariano Zavala & 3,63 & 13,2 \\
\hline & Juan José Castellano & 3,63 & 13,2 \\
\hline \multirow{2}{*}{ 1832-1835 } & José María Rodríguez & 4,25 & 18,1 \\
\hline & Leandro Gramajo & 4,25 & 18,1 \\
\hline
\end{tabular}

Fuente: elaboración propia con base en AHS, Sección Notariales, Protocolos notariales, Carpetas 23-28, protocolos desde el número

237 al 298 (periodo 1810-1835). Nota: sobre el cálculo de concentración véase gráfica 8.

dentro de la élite. Los primeros adhirieron a la causa del rey y colaboraron con los realistas cuando ocuparon militarmente la ciudad de Salta, mientras que los segundos tuvieron argumentos para sumarse a las filas patriotas" (p. 235). ${ }^{14}$

A pesar de las consecuencias estructurales negativas que le cupo al proceso revolucionario sobre el crédito, en particular, el periodo también incrementó un gradual proceso que expandió la disponibilidad crediticia. En efecto, se evidencia una concentración moderada entre deudores (1.725) menor a la concentración entre los acreedores (2.313). De cualquier forma, al identificar quiénes son los principales acreedores salteños del periodo, coexisten viejos actores (provenientes de los últimos años tardío-virreinales) con nuevos agentes, lo cual da cuenta del recambio generacional y la dinámica de sujetos en el grupo de principales prestamistas de cada perio-

14 La presencia de los comerciantes se hizo sentir en distintos resortes del poder político de la provincia, ya que llegaron a ocupar puestos claves para la toma de decisiones. Facundo Zuviría, Juan Marcos Zorrilla y Dámaso Uriburu se contaron entre los fundadores y dirigentes más conspicuos de Patria Nueva, grupo político opositor al sistema gobernante que comenzó a organizarse a partir de 1819 (Justiniano 2008, p. 236). 
Prestar en tiempos de guerra, cambio institucional y transformaciones sociopolíticas. El crédito notarial en Salta 1810-1835 doi: https://doi.org/10.21789/24222704.1518
TIEMPO \& ECONOMÍA Vol. 7 N. ${ }^{\circ} 1$ | Enero - Junio del 2020 pp. $210-245$

\begin{tabular}{|c|c|c|c|}
\hline Periodo & Acreedor/a & $\begin{array}{c}\% \text { escrituras } \\
\text { crédito otorgadas }\end{array}$ & $\begin{array}{c}\text { Grado de } \\
\text { concentración } \\
\text { sobre el total }\end{array}$ \\
\hline \multirow{3}{*}{$1810-1815$} & Antonio Águeda & 10,50 & 110,3 \\
\hline & José Patricio Baigorri & 5,20 & 27,4 \\
\hline & Antonio María Taboada & 5,20 & 27,4 \\
\hline \multirow{2}{*}{$1816-1821$} & Bonifacio Huergo & 8,30 & 68,9 \\
\hline & María Dolores Suárez & 8,30 & 68,9 \\
\hline \multirow{6}{*}{$1822-1826$} & José Hilario Carol & 12,05 & 145,2 \\
\hline & Juan Galo Leguizamón & 8,33 & 69,4 \\
\hline & José Ignacio Gorriti & 8,33 & 69,4 \\
\hline & Bonifacio Huergo & 6,25 & 39,1 \\
\hline & Joaquín Díaz de Bedoya & 4,16 & 17,3 \\
\hline & Guillermo Ormachea & 4,16 & 17,3 \\
\hline \multirow{7}{*}{$1827-1831$} & Pablo Alemán & 20,00 & 400,0 \\
\hline & Juan Galo Leguizamón & 7,27 & 52,9 \\
\hline & Francisco Claudio Castro & 5,45 & 29,7 \\
\hline & Aron Castellanos & 3,63 & 13,2 \\
\hline & Manuel Solá & 3,63 & 13,2 \\
\hline & Juana Isabel Díaz & 3,63 & 13,2 \\
\hline & Francisca Aguirre & 3,63 & 13,2 \\
\hline \multirow{5}{*}{$1832-1835$} & Manuel Solá & 8,51 & 72,4 \\
\hline & Atanacio Martínez Iriarte & 4,25 & 18,1 \\
\hline & Joaquín Díaz de Bedoya & 4,25 & 18,1 \\
\hline & Pío Hoyos & 4,25 & 18,1 \\
\hline & Mariano Antonio Echazú & 4,25 & 18,1 \\
\hline
\end{tabular}

Tabla 3.

Acreedores que concentraron la principal cantidad de obligaciones de pago otorgadas a su favor
Fuente: Elaboración propia en base a AHS, Sección Notariales, Protocolos notariales, Carpetas 23-28, protocolos desde el número 237 al 298 (periodo 18101835). Nota: Sobre el cálculo de concentración véase gráfico VIII. do. La tabla 3 hace mención a cada uno de los principales prestamistas de cada periodo.

El peninsular Antonio Águeda, principal acreedor durante 1810 y 1815 , fue un exitoso comerciante avecindado en Salta desde mediados del siglo XVIII. Puede considerarse como uno de los actores que constituyeron el recambio de la élite económica desde la década de los noventa y mantuvo sus negocios e intereses comerciales a pesar de los acontecimientos revolucionarios durante la primera década del siglo XIX. Su giro mercantil complementó la actividad comercial con el otorgamiento de créditos en dinero y bienes. Desde 1788 es posible rastrear sus primeras operaciones crediticias, las cuales permiten trazar sus relaciones con otros sujetos. Águeda otorgó 
préstamos a agentes de reconocida participación mercantil y política, como el hacendado, comerciante y político Isidoro Matorras, a quien transfirió un crédito el 17 de noviembre de 1803 por la cuantiosa suma de 2.000 pesos. $^{15}$

Águeda se posicionó social y económicamente de modo vertiginoso en la comunidad salteña tardo-virreinal, lo cual hizo de él un actor al cual acudieron comerciantes de otras latitudes virreinales para que los representara mercantilmente en la plaza salteña, como fue el caso de los hermanos altoperuanos Racines. Águeda solicitó préstamos en Salta a nombre de ellos el 26 de marzo de 1803 por un crédito de 14.207 pesos al hacendado cordobés Juan González Roldan para financiar el envío de mulas a nombre de sus representantes a los polos potosinos. ${ }^{16}$ Su derrotero personal da cuenta que para 1807 había ya consolidado su posición social al jurar el cargo militar de teniente del regimiento de voluntarios de caballería, el cual mantendría tras el estallido revolucionario.

Por su parte, la actividad económica de Bonifacio Huergo, principal acreedor en Salta entre 1816 y 1821, se caracterizó por el desarrollo de vínculos comerciales con actores del mercado de Buenos Aires dedicados al tráfico ultramarino y la redistribución regional de importaciones. Uno de sus socios fue Mariano Benítez, sindicado como importante comerciante de mulas, propietario de grandes haciendas al norte de Buenos Aires y residente en Salta. Huergo nació en la ciudad de Salta en 1800, hijo de José María de Jove Huergo y Hermenegilda Caínzos Mercado, oriundos de la ciudad de San Miguel de Tucumán. Su derrotero es un claro ejemplo de ascenso económico en tiempos coyunturales, puesto que mantuvo su posición en la élite económica salteña a pesar de los acontecimientos revolucionarios y los litigios políticos con Martín Miguel de Güemes. En 1825, Huergo alcanzó el cargo de juez de segunda instancia de la ciudad de Salta e integró el tribunal mercantil de la ciudad desde 1828. Más tarde se vinculó matrimonialmente el 13 de noviembre de 1832 con Trinidad Saravia Tejada, nacida en Salta en 1805, hija de Santiago Francisco Saravia, uno de sus principales socios del comercio, y Josefa Tejada, hija de Manuel Antonio Tejada, este último uno de los principales prestamistas tardío virreinales salteños a quien nos referimos páginas anteriores. La permanencia socioeconómica de Huergo se hace evidente en los siguientes años y durante el periodo 1822-1826 continúa siendo uno de los grandes acreedores de Salta (tabla 3). Aunque su

AHS, Sección protocolos notariales, caja núm. 20, protocolo núm. 205, Fs. 79 r.

AHS, Sección protocolos notariales, caja núm. 20, protocolo núm. 206, Fs. 13 r. 
preeminencia será desplazada paulatinamente por su contemporáneo José Hilario Carol, el principal prestamista entre 1822 y 1826.

Este último nació en 1793 en Santiago del Estero, hijo de Pedro Carol Maquet y Petrona Suárez Ledesma Balderrama. ${ }^{17}$ Se dedicó al comercio y el préstamo. Su trayectoria muestra las reorientaciones mercantiles que desplegaron estos actores tras los reordenamientos en el comercio regional posrevolucionario. Vinculado por algunos negocios en común con los hermanos Ceballos, Teodoro Correa, Juan Manuel Cornejo y Zenón e Inocencio Torino, quienes tenían sus cuentas en la casa comercial de Nicomedes García en el puerto de Cobija, además de Valeriano y Casimiro del Campo y Teodoro e Isidoro Sayus, quienes comerciaban través de la casa Artola e Hijos o Andrés Ugarriza, Hilario Carol se surtía a la vez de géneros para su venta en las tiendas salteñas y otras ciudades colindantes desde Valparaíso a través de la firma Corbalán (Conti, 2012).

En 1826, Carol se casó con Micaela Gorostiaga, hija de su socio comerciante José Ignacio Gorostiaga. Carol también se vinculó con los Uriburu y Vicente Anzoátegui, a quienes compraba efectos de ultramar para venderlos en Santiago y Tucumán. Su actividad política también fue elocuente y de larga trayectoria. Además, participó en la Coalición del Norte, siendo uno de los representantes salteños que intentó convencer a La Madrid que no entrara en Salta. A fines de la década de 1840, Carol se reincorporó a la Sala de Representantes como diputado y antes de Caseros fue elegido presidente del Cuerpo. Poco después, comenzó una relación epistolar con el gobernador de Santiago del Estero, Manuel Taboada.

Este hombre de negocios contribuyó de manera decisiva en la integración de los Uriburu en una escala regional y luego nacional, para terminar identificándose con los liberales porteños a finales del siglo XIX. Su desempeño como senador nacional por Santiago del Estero entre 1854 y 1857, formando parte de los llamados alquilones de Urquiza, puede considerarse un premio o recompensa al importante papel desempeñado (Quintián, 2012, p. 247-250).

Un perfil similar ofrece Pedro Pablo Antonio Alemán Rivera, acreedor que concentró la mayor participación en el circulo crediticio de todos los años analizados (tabla 3), hijo de Antonio Alberto Alemán y Gregoria Antonia Rivero Delgado Melilla, quien nació el 16 de agosto de 1791 en la Banda

17 Argentina, censo nacional, 1869. Database with images, Family Search (https://familysearch.org/ ark:/61903/1:1:M49Z-XCL). José Hilario Carol, Capital, Salta, Argentina; Archivo General de la Nación, Buenos Aires; FHL microfilm 686,896. 
Oriental, localidad de Canelones. ${ }^{18}$ El primer registro comercial ante notarios salteños a su nombre data del 28 de abril de 1825, otorgando un préstamo en efectos ultramarinos al comerciante Eusebio de Los Santos, lo cual indicaría que su traslado a Salta se ubicaría a inicios de la década del veinte, puesto que en esta escritura se reconoció definitivamente radicado como vecino y comerciante de la plaza salteña, y que, en segundo lugar, dedicó gran parte de su actividad a la introducción de efectos por Buenos Aires para su estipendio en Salta. ${ }^{19}$

La carrera comercial de Alemán Rivera se complementó con cargos políticos, constituyéndose al igual que sus pares, por ejemplo, desde 1828, en miembro del Tribunal Mercantil de la ciudad de Salta,${ }^{20}$ institución que lo benefició al momento de entablar vínculos sociales y mantener una posición sociopolítica relevante en la comunidad local. De hecho, fue el hombre a quien Martín Dorrego eligió en 1827 para llevar adelante la fracasada conspiración contra el gobierno unitario de José Ignacio Gorriti, último bastión de este signo en el norte después de la caída de Rivadavia. En 1832, Alemán accedió a la primera magistratura salteña en forma provisoria por delegación del gobernador Pablo Latorre. Más tarde, apoyado por los hermanos Alejandro y Felipe Heredia, se erigió como gobernador de la recientemente constituida provincia de Jujuy, el 28 de marzo de 1836. A partir de ese año, estableció una relación ambivalente con el mariscal de Bolivia y protector de la Confederación Peruano-boliviana, Andrés de Santa Cruz (Justiniano 2008, pp. 98-100).

De otro lado, Manuel Solá, principal acreedor del periodo 1832-1835, nació en Salta el 17 de julio de 1798. Hijo de Miguel Vicente Solá Inda y María Felipa Bernarda Tineo Castellanos, junto a sus hermanos Victorino y Fortunato, entretejió una red comercial que conectó Salta con otras latitudes transregionales. Esta red se extendió, por un lado, a su proveedor y comisionista en el puerto de Buenos Aires, Felipe Navarro, y a su clientela local y regional. Los negocios de los tres hermanos giraban alrededor de una empresa mercantil familiar y actividades ganaderas subsidiarias del comercio. Es muy probable que sus contactos comerciales en el puerto se debieran a su amistad

18 Argentina, Salta, registros parroquiales, 1634-1972. Database with images, FamilySearch (https:// familysearch.org/ark:/61903/1:1:XNCG-X4H: 12 August 2019). Pablo Alemán in entry for Eduviges Aleman, 1831.

19 AHS, sección protocolos notariales, Caja núm. 25, Protocolo núm. 273, Fs., 47r. La obligación otorgada por Eusebio ante el escribano público Félix Ignacio Molina a favor de Pablo Aleman fue por 982 pesos y 7 reales "(...) en efectos de Europa que tienen recibidos a precios corrientes de la plaza".

20 AHS, Boletín Oficial de 1828, fs. 100, 101 y 102. 
con Joaquín Díaz de Bedoya, comerciante, médico y político salteño, quien concentró el 17,3 \% de los préstamos otorgados entre 1822-1826 y el 18,1\% de los otorgados durante 1832-1835, quien a su vez formaba parte de la red mercantil organizada desde Buenos Aires por Juan Esteban de Anchorena a fines del siglo XVIII y comienzos del siglo XIX con comerciantes de Tucumán, Salta, Jujuy, Potosí y Chuquisaca (Conti, 2003). ${ }^{21}$

Las relaciones sociales de Solá se afianzaron al establecer matrimonio con Josefa Chavarría Moldes, lo cual emparentó a la familia Solá con los Moldes-Chavarría, quienes se reconocían de procedencia virreinal en la plaza y poseían reconocidos negocios mercantiles y crediticios establecidos con el fundador del grupo, Juan Antonio Moldes (Justiniano, Madregal, \& Anachuri 2019). Luego de establecer matrimonio, Solá firmó un contrato con Achával para vender paños alemanes en Buenos Aires -cuyo precio había subido en esa plaza y de los cuales Manuel Solá tenía más de 2000 varas en su tienda de Salta- o importar cascarilla y quina desde La Paz para su venta en Buenos Aires.

Los hermanos Solá no solo fueron grandes comerciantes y prestamistas contemporáneos, sino que además se constituyeron en una de las principales sociedades acreedoras del gobierno provincial. ${ }^{22}$ La carrera política de Manuel Solá se consolidaría al alcanzar finalmente en 1859 el cargo de Gobernador de la Provincia de Salta (Justiniano 2008, p. 60). A su muerte, el 23 de febrero de 1867, este empresario era poseedor de una de las fortunas salteñas más grande del periodo. ${ }^{23}$

\section{A modo de cierre}

Las transacciones crediticias rubricadas como obligación de pago arrojan valiosa información que da cuenta de los cambios, las continuidades y transformaciones sobre la economía de una sociedad en tránsito a una fidelidad estatal.

La coyuntura revolucionaria afectó considerablemente la dinámica comercial y a sus resortes últimos de financiación, como el crédito. En términos estructurales, se asistió a un profundo hundimiento de la actividad

21 En 1830, Manuel Solá y Joaquín Díaz de Bedoya formarían una sociedad mercantil de artículos de mercería y ferretería que consiguieran a muy bajos costos (Conti, 2003).

22 AM: CV, correspondencia de Manuel Solá de noviembre 22 de 1826.

23 Argentina, censo nacional, 1895. Database with images, FamilySearch (https://familysearch.org/ ark:/61903/1:1:MWWR-FVS: 5 September 2017), Victorino M. Solá, 1895; citing Sección 06 (Población urbana), Salta, Salta, Argentina, district Salta, source piece, Archivos Nacionales (National Archives), Buenos Aires. 
crediticia en las primeras décadas posrevolucionarias y a una lenta recuperación desde 1825, aunque esta tendencia nunca alcanzaría los niveles tanto en los volúmenes de valores acreditados ni de cantidad de escrituración de los últimos años virreinales. Este comportamiento en el círculo crediticio puede considerarse uno de los signos de que la economía salteña participó del proceso estacionario en la circulación y creciente desigualdad regional tras el desmoronamiento del orden virreinal en el virreinato del Río de la Plata.

Por otro lado, aun cuando los volúmenes acreditados y el número de escrituración cayeron significativamente en comparación con periodo tardo-virreinal, estos continuaron siendo engranajes fundamentales de financiamiento de la circulación de intercambios regionales establecidos desde periodos virreinales (anexo 2). Esto puede evidenciarse en la temporada de escrituración de obligaciones de pago en el primer semestre del año, momento en el cual se llevaba a cabo las tradicionales ferias mercantiles en las zonas colindantes a la plaza salteña.

Los cambios políticos, sociales e institucionales que trajo consigo el periodo de las revoluciones fomentó un doble movimiento en la estructura comercial. Mientras que el capital salteño avanzaba en las reorientaciones mercantiles propias de un periodo de transformación, los actores que concentraron el mayor número de compromisos crediticios pertenecían al recambio generacional de la época. Además, otros individuos, pocos en comparación a los primeros, provenían del grupo de comerciantes tardío virreinales en el espacio, quienes a pesar de las dificultades acaecidas tras la revolución mantuvieron estratégicamente su posición. Esto confirmaría que se mantuvo cierto dinamismo en aquella sociedad de la primera mitad del siglo XIX. Algunos miembros del pequeño grupo lograron un vertiginoso ascenso socioeconómico en un momento de profundas transformaciones, aunque pocos provenían de la última generación del periodo virreinal. Nuevos nombres comienzan a posicionarse y entablar duraderos vínculos sociales, haciendo del grupo político económico salteño una comunidad con fuertes influencias nacionales en la segunda mitad del siglo XIX.

Los primeros años posrevolucionarios (1810-1818) se caracterizaron por un elevado nivel de conflictos bélicos en la región, lo cual se tradujo en mayores riesgos, especulación e incertidumbre al momento de entablar compromisos crediticios. La guerra trastocó la fluidez del crédito, el comercio y la fiscalidad. Así mismo, la desorganización monetaria de los flamantes 
estados fue protesta corriente de estos actores, quienes vivían una época de cambios convulsionados y dejaban registros en las propias escrituras de créditos de estas dificultades.

A pesar de los contratiempos, propios de un momento coyuntural, el crédito siguió siendo un mecanismo de integración necesario que dotó de liquidez a unos circuitos que se recomponían y reorientaban a medida que se atravesaba la década del veinte. Paralelamente, Salta, antigua capital de la intendencia virreinal, consolidaba su nueva posición administrativa y territorial como provincia de frontera, mientras que las desigualdades regionales con el litoral y Buenos Aires aumentaban las asimetrías en el desarrollo económico de estos espacios persistentes en el largo plazo.

\section{Referencias}

Acevedo, E. (1965). La Intendencia de Salta del Tucumán en el Virreinato del Río de la Plata. Buenos Aires: Universidad Nacional de Cuyo.

Anachuri, M. G. (2019a). Créditos y fortunas. El caso de Juan Antonio Moldes en la Salta de fines del siglo XVIII. América Latina en la Historia Económica, 26(3), 1-25. https://doi.org/10.18232/alhe.972

Anachuri, M. G. (2019b). Relevancia e incidencia del crédito en la circulación de un nodo virreinal: Salta, 1788-1809. Anuario del CEEED, 11, 17-57.

Bonialian, M., \& Hausberger, B. (2018). Consideraciones sobre el comercio y el papel de la plata hispanoamericana en la temprana globalización, siglos XVI-XIX. Historia de México, 197-244. doi: https://doi. org/10.24201/hm.v68i1.3641

Cavieres, E. (1996). Del crédito tradicional colonial al crédito moderno. Perspectivas y fuentes. Chile: el crédito en la periferia. América Latina en la Historia Económica, 3(6), 21-31. https://doi.org/10.18232/alhe. v3i06.189

Conti, V. (2003). Circuitos mercantiles, medios de pago y estrategias en Salta y Jujuy (1820-1852). En M. A. Schmit. La desintegración de la economía colonial: comercio y moneda en el interior del espacio colonial (18001860) (pp. 113-133). Buenos Aires: Prometeo.

Conti, V. (2012). Los comerciantes de Salta y Jujuy durante las guerras civiles. Circuitos, mercados, capitales y redes. Ciudad de México: Universidad Nacional Autónoma de México. 
Conti, V., \& Jumar, F. (2010). El impacto de la independencia en las articulaciones y desarticulaciones regionales: ensayo comparativo entre la región Río de la Plata y la región Salto-jujeña. Memoria Académica. III Encuentro de la Red Internacional Marc Bloch. Universidad de la Plata, octubre 20-22.

Flynn, D., \& Giráldez, A. (1995). Born with a "Silver Spoon": The Origin of World Trade in 1571. Journal of World History, 6(2), 201-221.

Gelman, J. (2011). Desequilibrios regionales. Desigualdades sociales: Las economías argentinas en el siglo XIX. En J. Gelman (Coord). El mapa de la desigualdad (pp. 11-47). Rosario: Prohistoria.

Gelman, J. (2014). Los cambios en la economía atlántica entre los siglos XVIII y XIX. Desarrollo capitalista, globalización y desigualdad en América Latina. Nuevo Mundo. Mundos Nuevos, 1, 1-19. https://doi.org/10.4000/ nuevomundo.66288

Hespanha, A. M. (1996). Una nueva historia política e institucional . Revista Mexicana de Ciencias Políticas y Sociales, 9-45. https://doi. org/10.22201/fcpys.2448492xe.1996.166.49493

Jumar, F. (2012). La región Río de la Plata y su complejo portuario durante el Antiguo Régimen. En R. Fradkin. Historia de la Provincia de Buenos Aires (pp. 124-157). Buenos Aires: EDHASA.

Justiniano, M. F. (2008). Las familias. En M. F. Justiniano, La elite salteña, 18801916: Estrategias familiares y evolución patrimonial (pp. 57-99). Buenos Aires: Universidad Nacional de La Plata .

Justiniano, M. F., \& Tejerina, M. E. (2011). Notas para comprender las continuidades y transformaciones fiscales del siglo XIX. El caso de Salta. Escuela de Historia, 1-24.

Justiniano, M. F., Madregal, C. M., \& Anachuri, M. G. (2019). Juan Antonio Moldes: de criado a comerciante global y funcionario regio (Salta, Buenos Aires, Cádiz, Filipinas, 1764-1804). Revista de Indias, 79(276), 277. https://doi.org/10.3989/revindias.2019.013

Lloveras-de-Arce, G., \& Ontivero, D. M. (2004). Estudio de dos familias de élite en Salta durante el periodo colonial: el caso de los Arias Velazquez y Arias Rengel. Escuela de Historia, 3(1), 1-23.

Marichal, C. (2017). El peso de plata hispanoamericano como moneda universal del antiguo régimen (siglos XVI-XVIII). En S. T. Carlos Marichal. 
De la plata a la cocaína. Cinco siglos de Historia Económica de América Latina, 1500-2000 (pp. 37-76). México: Fondo de Cultura Económica.

Mata, S. (1999). Tierra en armas. Salta en la revolución. En S. Mata. Persistencias y cambios. Salta y el noroeste argentino 1770-1840 (pp. 151-173). Buenos Aires: Prohistoria.

Mata, S. (2000). Tierra y poder en Salta. El noroeste argentino en vísperas de la independencia. En S. Mata. Tierra y poder en Salta. El noroeste argentino en vísperas de la independencia (pp. 27-29; 181-242). Sevilla: Diputación.

Mata, S. (2009). Guerra, militarización y poder. Ejército y milicias en Salta y Jujuy, 1810-1816. Anuario IEHS, 24, 279-298.

Parolo, M. P. (2016). La construcción de la fiscalidad provincial en la primera mitad del siglo XIX. Tucumán, 1814-1854. En M. P. Herrera. Estado, impuestos y contribuyentes. La construcción del sistema fiscal en Tucumán en el siglo XIX (pp. 15-55). Rosario: Prohistoria. https://doi. org/10.30972/fhn.026889

Quintián, J. I. (2012). En J. I. Quintián, Una aristocracia republicana. La formación de la élite salteña 1850-1870 (pp. 247-250). Buenos Aires: Universidad de San Andrés.

Quirós, P. G. (2015). Introducción. Hacia un nuevo paradigma complejo y global. En P. G. Quirós. Independencias iberoamericanas. Nuevos problemas y aproximaciones (pp. 1-11). Ciudad de México: Fondo de Cultura Económica .

Santilli, D. (2013). ¿Perjudiciales o beneficiosas? La discusión sobre el impacto económico de las reformas borbónicas en Buenos Aires y su entorno. Fronteras de la Historia, 18(2), 247-283. https://doi. org/10.22380/2027468844

Wasserman, M. (2018). La obligación de pago: el crédito y la legal transgresión a las leyes. En M. Wasserman. Las obligaciones fundamentales. Crédito y consolidación durante el surgimiento de Buenos Aires (pp. 167187). Buenos Aires: Prometeo. 
Anexo 1.

Volumen en los ingresos y egresos desagregados de la Hacienda de Salta (1810-

1835)

\begin{tabular}{|c|c|c|c|c|c|c|c|}
\hline Periodo & Alcabalas & Sisas & $\begin{array}{l}\text { Existencia } \\
\text { total }\end{array}$ & Cargo & Data & $\begin{array}{c}\text { Gastos de } \\
\text { guerra }\end{array}$ & $\begin{array}{l}\text { Sueldos } \\
\text { políticos }\end{array}$ \\
\hline 1810 & $\$ 29.908$ & $\$ 31.947$ & $-\$ 61.012$ & $\$ 187.473$ & $\$ 248.485$ & $\$ 62.873$ & $\$ 11.416$ \\
\hline 1811 & $\$ 22.894$ & $\$ 25.204$ & $-\$ 53.961$ & $\$ 500.640$ & $\$ 554.601$ & $\$ 222.987$ & $\$ 8.314$ \\
\hline 1812 & $\$ 2.109$ & $\$ 3.810$ & $\$ 5.287$ & $\$ 6.363$ & $\$ 1.076$ & $\$ 255$ & $\$ 700$ \\
\hline 1813 & $\$ 12.909$ & $\$ 8.542$ & $-\$ 70.405$ & $\$ 139.556$ & \$ 209.961 & $\$ 65.729$ & $\$ 9.308$ \\
\hline 1814 & $\$ 13.786$ & $\$ 3.342$ & $-\$ 11.210$ & $\$ 88.288$ & $\$ 99.498$ & $\$ 67.444$ & $\$ 9.596$ \\
\hline 1815 & $\$ 12.403$ & $\$ 10.973$ & $\$ 170.464$ & $\$ 228.283$ & $\$ 57.819$ & $\$ 42.486$ & $\$ 4.710$ \\
\hline 1816 & $\$ 6.354$ & $\$ 13.045$ & $\$ 192.412$ & $\$ 231.819$ & $\$ 39.407$ & $\$ 23.576$ & $\$ 1.014$ \\
\hline 1817 & $\$ 3.719$ & $\$ 16.276$ & $\$ 212.593$ & $\$ 235.121$ & $\$ 22.528$ & $\$ 18.267$ & $\$ 890$ \\
\hline 1818 & $\$ 7.563$ & $\$ 15.400$ & $\$ 224.831$ & $\$ 239.693$ & $\$ 14.862$ & $\$ 11.541$ & $\$ 755$ \\
\hline 1819 & $\$ 4.166$ & $\$ 16.797$ & $\$ 250.621$ & $\$ 270.631$ & $\$ 20.010$ & $\$ 18.291$ & $\$ 15$ \\
\hline 1820 & $\$ 3.628$ & $\$ 19.942$ & $\$ 260.537$ & $\$ 290.654$ & $\$ 30.117$ & $\$ 19.191$ & $\$ 74$ \\
\hline 1821 & $\$ 2.789$ & $\$ 14.521$ & $\$ 5.888$ & $\$ 23.456$ & $\$ 17.568$ & $\$ 14.589$ & $\$ 45$ \\
\hline 1822 & $\$ 8.035$ & $\$ 7.777$ & $\$ 13.853$ & $\$ 25.990$ & $\$ 12.137$ & $\$ 6.158$ & $\$ 271$ \\
\hline 1823 & $\$ 14.197$ & $\$ 12.064$ & $\$ 32.490$ & $\$ 49.780$ & $\$ 17.290$ & $\$ 8.498$ & $\$ 858$ \\
\hline 1824 & $\$ 12.672$ & $\$ 12.401$ & $\$ 54.531$ & $\$ 111.815$ & $\$ 57.284$ & $\$ 39.515$ & $\$ 1.656$ \\
\hline 1825 & $\$ 18.362$ & $\$ 12.908$ & $\$ 72.899$ & $\$ 153.793$ & $\$ 80.894$ & $\$ 45.576$ & $\$ 1.042$ \\
\hline 1826 & $\$ 16.051$ & $\$ 16.469$ & $\$ 102.950$ & $\$ 167.790$ & $\$ 64.840$ & $\$ 3.297$ & $\$ 549$ \\
\hline 1827 & $\$ 4.773$ & $\$ 20.568$ & $\$ 96.094$ & $\$ 166.408$ & $\$ 70.314$ & $\$ 46.448$ & $\$ 4.578$ \\
\hline 1828 & $\$ 8.882$ & $\$ 2.779$ & $\$ 6.668$ & $\$ 33.619$ & $\$ 26.951$ & $\$ 6.478$ & $\$ 9.919$ \\
\hline 1829 & $\$ 7.890$ & $\$ 2.397$ & $\$ 19.999$ & $\$ 45.692$ & $\$ 25.693$ & $\$ 3.500$ & $\$ 9.912$ \\
\hline 1830 & $\$ 7.803$ & $\$ 2.280$ & $\$ 1.037$ & $\$ 38.485$ & $\$ 37.448$ & $\$ 4.230$ & $\$ 9.156$ \\
\hline 1831 & $\$ 6.897$ & $\$ 2.014$ & $\$ 89.185$ & $\$ 91.685$ & $\$ 2.500$ & $\$ 1.700$ & $\$ 500$ \\
\hline 1832 & $\$ 6.637$ & $\$ 1.664$ & $\$ 292$ & $\$ 104.466$ & $\$ 104.174$ & $\$ 36.457$ & $\$ 11.768$ \\
\hline 1833 & $\$ 14.595$ & $\$ 3.532$ & $-\$ 6.977$ & $\$ 64.000$ & $\$ 70.977$ & $\$ 19.618$ & $\$ 19.422$ \\
\hline 1834 & $\$ 14.698$ & $\$ 3.019$ & $-\$ 1.279$ & $\$ 71.509$ & $\$ 72.788$ & $\$ 23.387$ & $\$ 19.228$ \\
\hline 1835 & $\$ 11.663$ & $\$ 1.222$ & $\$ 2.506$ & $\$ 39.432$ & $\$ 36.926$ & $\$ 16.663$ & $\$ 10.347$ \\
\hline
\end{tabular}

Fuente: Elaboración propia con base en el desagregado de los Libros de Hacienda. AHS, Sección: Hacienda, Libros Mayores 1810- 
Prestar en tiempos de guerra, cambio institucional y transformaciones sociopolíticas. El crédito notarial en Salta 1810-1835 doi: https://doi.org/10.21789/24222704.1518
TIEMPO \& ECONOMÍA

Vol. 7 N.o 1 | Enero - Junio del 2020

pp. $210-245$

Anexo 2.

Valores anuales acreditados a través obligaciones de pago y cantidad de escrituras realizadas en el largo plazo. Salta 1770-1835 (tendencia temporal)

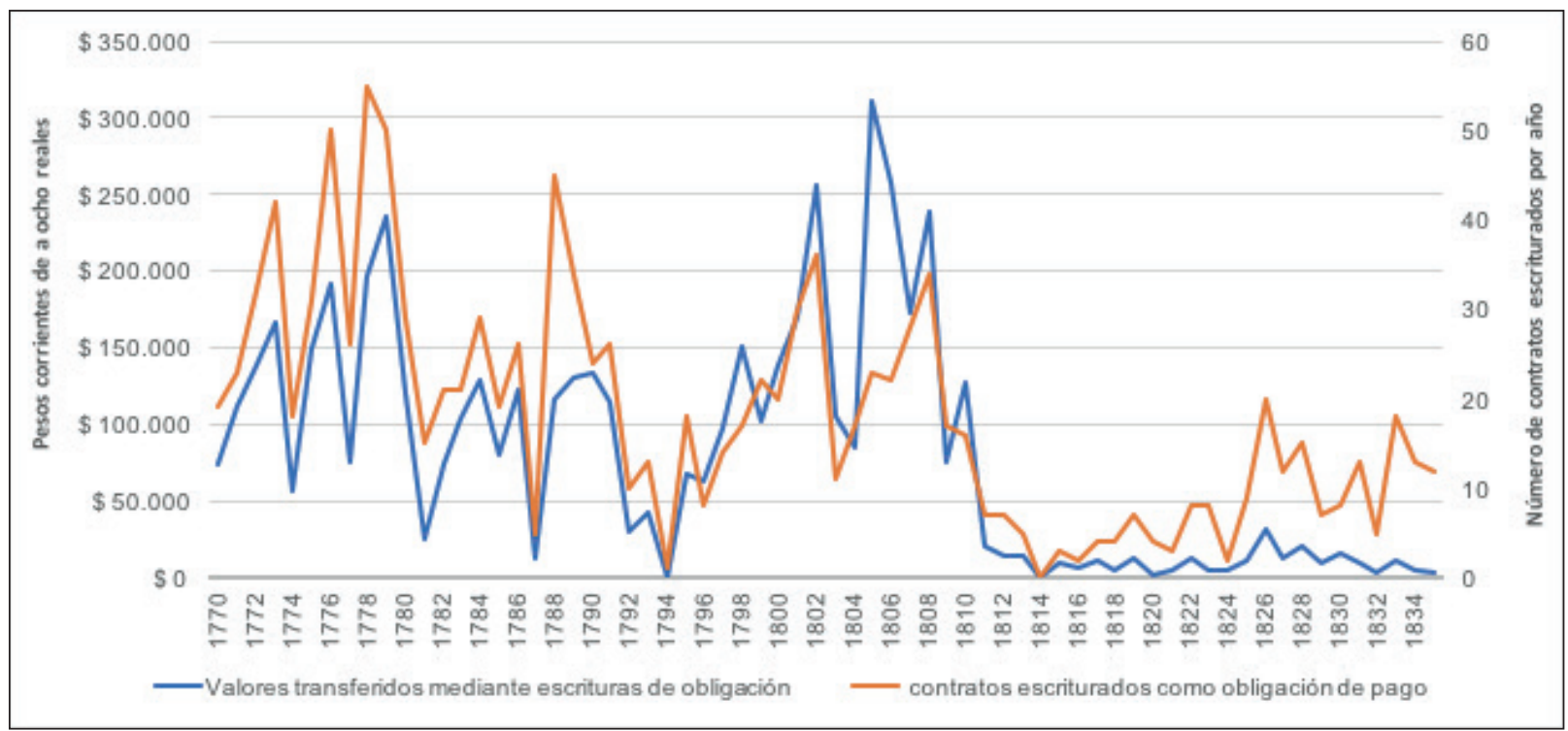

Fuente: Elaboración propia con base en el relevamiento de las obligaciones de pago. Archivo Histórico de Salta sección protocolos notariales, carpeta núm. 147-231, protocolos núm. 147-231 (1770-1809) y AHS, Sección Notariales, Protocolos notariales, Carpetas 23-28,

protocolos desde el número 237 al 298 (1810-1835)

Nota: Valores en términos nominales. 
TIEMPO \& ECONOMÍA

Anexo 3.

Ciudades a las cuales se dirigieron las obligaciones de pago registradas en Salta

(1810-1835)

\begin{tabular}{|c|c|c|c|c|c|c|c|c|}
\hline Periodo & Ciudad & $\begin{array}{l}\text { Cantidad de } \\
\text { préstamos }\end{array}$ & $\begin{array}{c}\text { Participación } \\
\text { (\%) }\end{array}$ & $\begin{array}{c}\text { Valores } \\
\text { transferidos }\end{array}$ & Periodo & $\begin{array}{c}\text { Cantidad de } \\
\text { préstamos }\end{array}$ & $\begin{array}{c}\text { Participación } \\
\text { (\%) }\end{array}$ & $\begin{array}{c}\text { Valores } \\
\text { transferidos }\end{array}$ \\
\hline $1810-1820$ & Salta & 46 & 77,96 & $\$ 211.444$ & $1821-1835$ & 121 & 79,08 & $\$ 128.508$ \\
\hline & Cachi & 1 & 1,69 & $\$ 1.389$ & & 1 & 0,65 & $\$ 250$ \\
\hline & San Carlos & 1 & 1,69 & $\$ 300$ & & 0 & & \\
\hline & Oran & 0 & - & - & & 2 & 1,30 & $\$ 150$ \\
\hline & Seclantas & 0 & - & - & & 1 & 0,65 & $\$ 50$ \\
\hline & La Caldera & 0 & - & - & & 1 & 0,65 & $\$ 135$ \\
\hline & San Agustín & 0 & - & - & & 1 & 0,65 & $\$ 200$ \\
\hline & Payogasta & 0 & - & - & & 1 & 0,65 & $\$ 66$ \\
\hline & $\begin{array}{c}\text { Santiago del } \\
\text { Estero }\end{array}$ & 3 & 5,08 & $\$ 4.774$ & & 0 & - & - \\
\hline & Potosí & 2 & 3,38 & $\$ 3.249$ & & 0 & - & - \\
\hline & La Plata & 3 & 5,08 & $\$ 1.954$ & & 0 & - & - \\
\hline & Chichas & 1 & 1,69 & $\$ 2.512$ & & 0 & - & - \\
\hline & Tarija & 1 & 1,69 & $\$ 850$ & & 3 & 1,96 & $\$ 7.925$ \\
\hline & Tucumán & 1 & 1,69 & $\$ 340$ & & 0 & & \\
\hline & Villazón & 0 & - & - & & 1 & 0,65 & $\$ 550$ \\
\hline & Cochabamba & 0 & - & - & & 11 & 7,18 & $\$ 10.827$ \\
\hline & Portugalete & 0 & - & - & & 1 & 0,65 & $\$ 203$ \\
\hline & Ayacucho & 0 & - & - & & 2 & 1,30 & $\$ 6.470$ \\
\hline & San Juan & 0 & - & - & & 1 & 0,65 & $\$ 54$ \\
\hline & La Rioja & 0 & - & - & & 2 & 1,30 & $\$ 4.490$ \\
\hline & Sinti & 0 & - & - & & 1 & 0,65 & $\$ 2.000$ \\
\hline & Jujuy & 0 & - & - & & 1 & 0,65 & $\$ 400$ \\
\hline & Tupiza & 0 & - & - & & 2 & 1,30 & $\$ 289$ \\
\hline
\end{tabular}

Fuente: elaboración propia con base en AHS, Sección Notariales, Protocolos notariales, Carpetas 23-28, protocolos desde el número 237 al 298 (1810-1835). 